\title{
Co -curricular involvement of West Virginia four-year state college students and the statistical relationship with post -graduate community and professional involvement, leadership, salary, and job satisfaction
}

James D. Carpenter

West Virginia University

Follow this and additional works at: https://researchrepository.wvu.edu/etd

\section{Recommended Citation}

Carpenter, James D., "Co -curricular involvement of West Virginia four-year state college students and the statistical relationship with post -graduate community and professional involvement, leadership, salary, and job satisfaction" (2002). Graduate Theses, Dissertations, and Problem Reports. 2410.

https://researchrepository.wvu.edu/etd/2410

This Dissertation is protected by copyright and/or related rights. It has been brought to you by the The Research Repository @ WVU with permission from the rights-holder(s). You are free to use this Dissertation in any way that is permitted by the copyright and related rights legislation that applies to your use. For other uses you must obtain permission from the rights-holder(s) directly, unless additional rights are indicated by a Creative Commons license in the record and/ or on the work itself. This Dissertation has been accepted for inclusion in WVU Graduate Theses, Dissertations, and Problem Reports collection by an authorized administrator of The Research Repository @ WVU.

For more information, please contact researchrepository@mail.wvu.edu. 


\title{
CO-CURRICULAR INVOLVEMENT OF WEST VIRGINIA FOUR-YEAR STATE COLLEGE STUDENTS AND THE STATISTICAL RELATIONSHIP WITH POST-GRADUATE COMMUNITY AND PROFESSIONAL INVOLVEMENT, LEADERSHIP, SALARY, AND JOB SATISFACTION
}

\author{
James D. Carpenter \\ Dissertation submitted to the \\ College of Human Resources and Education at \\ West Virginia University \\ in partial fulfillment of the requirements \\ for the degree of
}

Doctor of Education

in

Educational Leadership

\author{
Michael Cunningham, Ed.D., Chair \\ Ernest Goeres, Ph.D. \\ Barbara Nicholson, Ph.D. \\ Rudy Pauley, Ed.D. \\ Jack E. Yeager, Ed.D.
}

Department of Advanced Education Studies

Morgantown, West Virginia

2002

Keywords: Student Affairs, Student Activities, Community Involvement, Student Leadership, Student Organizations

Copyright 2002 by James D. Carpenter 


\begin{abstract}
CO-CURRICULAR INVOLVEMENT OF WEST VIRGINIA

FOUR-YEAR STATE COLLEGE STUDENTS AND THE STATISTICAL RELATIONSHIP WITH POST-GRADUATE COMMUNITY AND PROFESSIONAL INVOLVEMENT, LEADERSHIP, SALARY, AND JOB SATISFACTION
\end{abstract}

The purpose of this study was to examine the statistical relationship between cocurricular involvement of West Virginia college students and post-graduate involvement in community and professional organizations, leadership positions held within those organizations, professional salary, and self-perceived job satisfaction. A sample population of 400 college students $(n=400)$ from State-supported colleges in West Virginia who completed baccalaureate requirements in 1990 was sent a copy of the West Virginia College and Community Involvement Survey and the Mohrman-Cooke-Mohrman Job Satisfaction Survey. Of 272 usable surveys, 142, or $52.2 \%$, were returned.

Data analysis identified a significant statistical correlation between involvement in collegiate co-curricular activities and involvement in community organizations. A similar statistically significant correlation was found to exist between college involvement and the holding of leadership positions within community and professional organizations. Significant relationships were not found to exist between co-curricular involvement and post-graduate professional involvement, salary, and self-perceived job satisfaction. 


\section{Table of Contents}

Title

Abstract

Table of Contents

List of Tables

iii

Table of Appendices

Acknowledgments

Chapter One

vii

Introduction

1

Background 3

Co-Curricular Involvement and Post-Graduate Characteristics 12

$\begin{array}{ll}\text { Statement of the Problem } & 15\end{array}$

$\begin{array}{ll}\text { Objective of the Study } & 16\end{array}$

$\begin{array}{ll}\text { Research Questions } & 17\end{array}$

$\begin{array}{ll}\text { Operational Definitions } & 18\end{array}$

$\begin{array}{ll}\text { Significance of the Study } & 19\end{array}$

Limitations of the Study $\quad 21$

Chapter Two 23

Review of the Literature 23

A Synopsis of Involvement and Leadership 26

The Need for Involvement $\quad 30$

The Evolution of Co-Curricular Activities in College 33

The Emergence of Student Development 36

Student Development and Co-Curricular Activities $\quad 41$

Co-Curricular Involvement and Post-Graduate Characteristics 43

Community and Professional Involvement 45

Co-Curricular Involvement and Leadership Positions 47

Salary 49

Job Satisfaction $\quad 51$

Summary $\quad 52$ 
$\begin{array}{ll}\text { Chapter Three } & 54\end{array}$

$\begin{array}{ll}\text { Methods } & 54\end{array}$

Design $\quad 54$

$\begin{array}{lr}\text { Population and Sample } & 55\end{array}$

Instrumentation $\quad 55$

$\begin{array}{ll}\text { Methods } & 57\end{array}$

Data Analysis $\quad 58$

$\begin{array}{ll}\text { Summary } & 59\end{array}$

$\begin{array}{ll}\text { Chapter Four } & 61\end{array}$

Introduction 61

Descriptive Data $\quad 62$

Scoring of the Instrument 63

Statistical Analysis of the Data $\quad 64$

Major Findings $\quad 65$

$\begin{array}{ll}\text { Ancillary Findings } & 70\end{array}$

Summary $\quad 75$

$\begin{array}{ll}\text { Chapter Five } & 77\end{array}$

Summary of Purpose $\quad 77$

Summary of the Procedures $\quad 78$

Summary of Descriptive Data $\quad 79$

Summary of Findings $\quad 80$

Conclusions $\quad 82$

Implications $\quad 86$

Recommendations for Further Research $\quad 94$

$\begin{array}{ll}\text { Bibliography } & 96\end{array}$

$\begin{array}{ll}\text { Appendices } & 107\end{array}$

$\begin{array}{ll}\text { Curriculum Vitae } & 117\end{array}$ 


\section{List of Tables}

Table 1. Correlation Coefficients Between Collegiate Involvement and Community Involvement

Table 2. Correlation Coefficients Between Collegiate Involvement and Post-Graduation Professional Involvement

Table 3. Correlation Coefficients Between Collegiate Involvement and Post-Graduation Community and Professional Leadership Positions

Table 4. Correlation Coefficients Between Collegiate Involvement and Reported Current Salary

Table 5. Correlation Coefficients Between Collegiate Involvement and Reported Intrinsic, Extrinsic, and Overall Job Satisfaction

Table 6. Correlation Coefficients Between Post-Graduation Community Involvement and Involvement in Religious, Recreational, and Professional Organizations

Table 7. Correlation Coefficients Between Post-Graduate Community Involvement and the Holding of Leadership Positions Within Organizations

Table 8. Correlation Coefficients Between Intrinsic, Extrinsic, and Overall Job Satisfaction and Post-Graduation Community Involvement

Table 9. Correlation Coefficients Between Intrinsic, Extrinsic, and Overall Job Satisfaction and Post-Graduate Leadership Involvement

Table 10. Correlation Coefficients Between Salary and Intrinsic, Extrinsic, and Overall Job Satisfaction

Table 11. Correlation Coefficients Between Reported Salary and Sex 


\section{Table of Appendices}

Appendix A: The West Virginia College and Community Involvement Survey 108

Appendix B: The Mohrman-Cooke-Mohrman Job Satisfaction Survey 111

Appendix C: Cover Letter to Sample Population 113

Appendix D: Follow-Up Letter to Sample Population 115 


\section{Acknowledgments}

I read somewhere that what we become in life is the sum result of the experiences we have had. I have been very blessed to have had some wonderful experiences and to have been surrounded by some wonderful people.

One of the most critical things a doctoral student does is pick a committee. Having no idea who any of the faculty members were when I started this program, I approached (then) complete strangers and asked a group of them to guide and judge me throughout the program. In retrospect, I don't think I could have chosen better. They have done the scholarly thing and passed their wisdom to the next generation of students. Along the way, they became mentors as well as friends. Dr. Ernest Goeres, Dr. Barbara Nicholson, Dr. Rudy Pauley, and especially Dr. Jack Yeager have all had a tremendous impact on my education and I hope to make them proud. Dr. Michael Cunningham, who became my chair (and probably now wonders why), has been a treasure of advice, information, and inspiration. He pushed me when I needed a push, kept me grounded when I got in a hurry, and cajoled my frustrations along the way. We have shared many laughs and stories during my journey.

Appreciation is also due to a wonderful faculty who helped, including Dr. Powell Toth, Dr. Ken Young, Dr. Dennis Prisk, Dr. Teresa Eagle, and especially Dr. Paul Leary. Dr. Leary turned the daunting task of writing a dissertation into almost a fun exercise (almost). From advice about style, content, and technical issues, to counsel and guidance through a difficult career move, Dr. Leary was always there and a tremendous source of encouragement.

I have been fortunate enough to receive direction and help from a wonderful group of people whom I have called "boss" during the past dozen or so years. I hope to continue to exemplify the attributes they instilled in me. Dale Geiger, Ralph Patsel, Dr. Louis Barsi, John Cardwell, and Dr. Susan Miller all continue to serve as confidants, friends, and educators. My "education outside of the classroom" I learned from them - and the others at Concord College, Bluefield State College, and Mountain State University.

The success and failure of many a student has been dictated by their peer group or cohort. Again, though divine guidance I suppose, I was blessed with the best. $D r$. Andy Blackwood, $D r$. Crissy Lauber, and Dr. Jill Hopkins have been my classmates and friends. I was the first out of the gate, but somehow they all defended before I did. We shared classes, frustrations, dissertation drafts, e-mails, projects, and, most of all, encouragement for each other. Jill and I shared about 15,000 miles driving to and from class together during the course of two years. You can't help but love someone after an experience like that.

Finally, and my greatest blessings, are my wife Lisa and mother Jean. Mom always told me she wanted to have a doctor in the family, though I doubt this is what she had in mind. I strive to live the kind of life that will do justice to all she has given me. Lisa has been a source of inspiration throughout our marriage (and completed her master's in the course of me completing this program). I will consider my life a success if I can show half the spirit, compassion, and patience that she has. Lisa taught me the true meaning of "soul mate." With this program, they have had only a part-time husband/son for several years now. I have a lot of catching up to do. 


\section{Chapter One}

\section{Introduction}

The development of active citizens and student leaders has often been cited as an important mandate for colleges (Bialek and Lloyd, 1998; Byer, 1998; National Association of Student Personnel Administrators, 1987; Newton, 1975; Smitter, 1998). Striffolino and Saunders (1989) encouraged student affairs professionals to take an active and aggressive role in the development of students, not only as scholars, but as citizens as well. If it is a basic assumption that human development is an organizing purpose for higher education (Chickering and Reisser, 1993), and if colleges and universities are charged with producing leaders (McIntyre, 1989), then the significance of providing opportunities for student involvement and leadership development is apparent.

Researchers have studied the relationship between involvement in college and subsequent involvement and the holding of leadership positions after graduation. Sawyer (1999) reported that students involved in leadership and service-type activities reported a higher degree of personal growth and development. Sawyer also cited other studies which confirmed that students actually perform better academically when they are involved in service or leadership activities.

Wilson (1966) found that $70 \%$ of what students perceived was learned during their college career can be attributed to experiences occurring outside the classroom. Another study by Moffatt (1989), which was quoted extensively throughout the literature (Chickering and Reisser, 1993; Kuh, 1995; Kuh and Lund, 1994), found that 
the most significant educational experiences in college, as perceived by $40 \%$ of students surveyed, involved activities of a co-curricular nature.

If participation in student activities and involvement in leadership activities is important in the development of a person, then the benefits and characteristics of that development should appear after the student graduates and enters society and the workforce. Numerous studies over the past half century have attempted to measure the impact of involvement and leadership development on college students after graduation (Burton, 1974; Florestano, 1970; Roskens, 1958; Sommers, 1991) and much has been written about the subject (Bialek and Lloyd, 1998; Byer, 1998; Downey, Bosco and Silver, 1984; Frederick, 1959; Schuh and Laverty, 1983; Sermersheim, 1996). If professionals in higher education are to continue to develop and work with student involvement and student leadership programs, it becomes imperative to ascertain if the efforts required to provide such opportunities are resulting in the desired and appropriate effect.

The purpose of this study is to build upon the foundations laid by Burton (1974), Florestano (1971), Roskens (1958), and Sommers (1991). Each of the aforementioned dissertations attempted to discover the benefit of co-curricular involvement and leadership activities by college students and the statistical relationships with later success in their civic lives and careers. These researchers, however, sampled graduates who were pre-selected as leaders or as having a high level of involvement on their campuses. The research results were then compared with established norms on leadership inventories and statistical information on college graduates. Many of the 
sample populations studied were also limited to graduates of only one or two campuses, and the two earliest studies examined only male students.

This study compared graduates of four-year State colleges in West Virginia who completed degree requirements for graduation in May 1990. Based on survey responses as to the graduates' co-curricular activities, respondents were categorized as either an involved or uninvolved student. The two groups were then compared in terms of postgraduate social/civic involvement, professional involvement, post-graduate leadership positions held in these organizations, salary, and self-perceived job satisfaction. The goal of this study was to determine if involvement in co-curricular activities while enrolled in a baccalaureate program at a State college in West Virginia had a statistical relationship with subsequent community and civic involvement, professional involvement, salary, and self-perceived job satisfaction and were the differences between students categorized as involved in co-curricular activities and those categorized as uninvolved were significant.

\section{Background}

\section{A Synopsis of Involvement and Leadership}

Prior to 1930 , there was little history of inquiry regarding leadership abilities, theories in leadership, and the attributes and distinctions of varying types of leaders (Florestano, 1971). Much of the foundation for the development of leadership theory was established by a study conducted by Lewin, Lippitt and White (1939). In the aforementioned study, aggressive behavioral patterns were examined. From Lewin, 
Lippitt, and White's work, there arose a research focus on personality characteristics and the qualities of a leader. Over time, Lewin, Lippitt and White's research evolved into the style perspective, out of which emerged four general theories of leadership: universal trait, universal behavior, situational trait, and situational behavior (Behling and Rauch, 1985). These theories are listed chronologically in order of their development (Burton, 1974).

Burton (1974) commented that the traits approach was one of the earliest used in attempting to study leadership. Students of trait theory believed that a leader could be identified as possessing certain traits. Walsh (1970) described the period ushering in the second era of leadership study as the situational or behavior period or the "times make the man" approach. It was illustrated that leaders emerged based on the specific needs of a particular time. Many of the elements and theories of leadership are rooted in these early foundations, although the definitions and number of theories have grown significantly over the years (Doherty, 1995).

Bowman (1997) discussed the continued development of leadership theory over the last decade of the 1900 s, specifying that much of the theory development was now written in a pragmatic and popular style for general readers outside of academe. It was suggested that many of the newer theories had three recurring themes. First, there was a servant-leader paradigm in which leaders must shift their focus from their own needs to the needs of their followers. The second involved the spiritual-ethical orientation and the premise that more attention focused on character, integrity, trust, and honesty would result in happier, and thereby more productive, followers. Finally, the empowerment of 
followers and the building of teams and collaboration to accomplish organizational objectives created credibility within the followers and helped achieve organizational goals. The theories and applications related to leadership, leadership development, and the involvement of members of a community or organization are applicable not only in work environments, but also with regard to social, civic, and professional involvement and leadership in the community. Over time, society's understanding of involvement and leadership and how these concepts function in contemporary organizations has been influenced by the integration of many of the theories discussed earlier (Komives, Lucas, and McMahon, 1998). Johnson (2000), related how the work of Komives, Lucas, and McMahon is directed toward college students and their development as involved and informed citizens and competent leaders.

\section{The Need for Involvement}

Paul (1992) explained that a guiding principle of student development theory was to educate students regarding responsibility for self-development and for community contributions. Paul's goal was to teach students to use influence to effect desirable change in the community and in organizations.

People have volunteered in the community and in professional organizations for a litany of reasons. These have included: (a) to feel needed, (b) to share a skill, (c) to donate professional skills, (d) to gain leadership skills, (e) to do a civic duty, and (f) because of satisfaction from accomplishment (Ellis, 2000). Perkins and Miller (2000) asserted that communities foster and encourage healthy development by involving all people and creating a sense of belonging and shared purpose. They indicated that a 
primary path to achieve that goal was through participation and leadership in civic organizations. Perkins and Miller also associated such involvement with furthering a person's (a) intellectual development, (b) social development, (c) psychological development, and (d) political efficacy and citizenship.

According to Watts (1988), community involvement, including the holding of leadership positions, and the provision of educational opportunities toward that end, was critical for the development of both individuals and communities. Graham and Cockriel (1995) correlated that critical individual and community development with the need for institutions of higher education to address the personal development needs of students. Graham and Cockriel's research indicated that involvement and leadership in college contributed to intra-personal development, personal valuing and moral development, community leadership and development, and civic involvement and awareness.

One place where people can apprentice involvement and leadership skills is during the completion of college coursework (Kuh, 1995). Chickering and Reisser (1993) described the college experience as a time when students could not only learn the theories of development, community, and leadership in the classroom, but could put those theories into practice through participation in co-curricular activities. Kuh explained that a multitude of benefits, including social competence, autonomy, selfconfidence, and an appreciation for human diversity were the result of such involvement. Involvement in co-curricular activities was found by Bialek and Groves (1998) to have historically enhanced leadership development and skills. The student affairs model of training college students in areas of leadership and interaction, whereby 
students are provided training through practical experience and instruction while participating in co-curricular activities, has been the dominant force in preparing these students (McIntire, 1989).

\section{The Evolution of Co-Curricular Activities in College}

Robert W. Frederick established the term third curriculum in 1959. After the required (or first) curriculum, consisting of major subjects, and the elective (or second) curriculum of courses thought to suit the individual needs and ambitions of the student, the third curriculum consisted of activities which met certain criteria. These criteria were (a) voluntary participation by students, (b) approval by institutional authorities, (c) faculty or staff sponsorship, and (d) an activity void of academic credit (Frederick, 1959).

The evolution of and belief in the value of co-curricular activities parallels the values placed on recreational and leisure activity throughout American culture. In 1815, the first college union was formed at Cambridge University in England. It was literally a union of three debating societies which built a common building for living quarters, debating, offices, and activities (Association of College Unions International, 1982). In an effort to purport similar ideals, the first college union in America was established by Harvard in 1832, specifically for debating purposes. The first of what could be called a modern student union, with lounges, dining rooms, an auditorium and cafeteria, however, did not appear until 1896, at the University of Pennsylvania.

During the period after the Civil War, significant changes in higher education led to the emergence of student affairs work. The character of higher education institutions 
evolved from a homogeneous demographic with a curriculum based on religious foundations to an objective of educating a responsible and enlightened citizenship as well as vocational training (National Association of Student Personnel Administrators, 1987). Prior to this period of change, the concept of in loco parentis (in the place of the parents) had been the guiding relationship between higher education institutions and students since $17^{\text {th }}$ Century England (Lucas, 1996; Sommers, 1991). During the later 1800 s, however, the dominance of the debate and literary societies was replaced by growth and interest in social fraternities and intercollegiate athletics (Brubacher and Rudy, 1974). Brubacher and Rudy also reviewed a fundamental shift in thinking during this time from in loco parentis to a more German influenced laissez-faire attitude toward student life outside the classroom. One reason for this change was a changing dynamic among American faculty, many of whom were pursuing graduate work in Germany where a more relaxed attitude toward students' activities beyond the classroom was prevalent (NASPA, 1987).

According to the researchers for NASPA (1987), the response of institutional presidents to this emerging phenomena was to appoint persons to handle matters regarding student problems and discipline. Other managers were appointed to what was labeled as the administration, including student activities advisors, as students began to look toward each other for social and intellectual stimulation (Chickering and Reisser, 1993). The renaissance in this area occurred generally after World War II with the passage of the G.I. Bill and the tremendous influx of students into the higher education system (Trow, 1997). 
With the aforementioned paradigm in place, academe entered into a period which Frederick (1959) termed the period of exploitation. This period was viewed by Frederick rather negatively and was seen as a time when the motivating factor for student involvement was to produce some benefit to an institution, teacher, coach, or administrator. Several years later, however, exploitation evolved into the use of cocurricular activities to foster student development outside the classroom and allow for the personal development of the student and the application of learned skills outside the classroom (Chickering and Reisser, 1993). With the realization that co-curricular activities led to the personal growth of students, interest in the social and emotional growth of students became a concern of many institutions of higher education.

\section{The Emergence of Student Development}

With the advent of the realization that participation in co-curricular activities led to the development of students as individuals, increased retention, and enhanced graduation rates (Morrell and Morrell, 1986), came an increase in the interest of purposefully developing these qualities and experiences for students (Chickering and Reisser, 1993). Chickering and Reisser introduced eight key factors to what they believed influenced the development of students. These factors were: a clear and consistent institutional mission, institutional size, student-faculty relationships, curriculum, teaching, friendships and student communities, student development programs and services, and creating an educationally powerful environment.

During the 1960 s to 1990 s, research into the area of student development exploded with a resulting plethora of theories on how and why college students develop 
as they do. Pascarella and Terenzini (1991) wrote what was considered to be the definitive work on student development theory (Chickering and Reisser, 1993). They grouped the varying student development theories into four main categories. Authors of psycho-social theories described how students developed through a series of stages or tasks that progressed from one to the next. Cognitive theories revealed how students developed thinking skills and the evolution of students' frames of reference. Typology theories provided for development in terms of an individual's learning style, personality type, or socioeconomic background. Person-environment interaction theories focused on the combination of individual characteristics with environmental influences and the resulting effect on the development of an individual (Pascarella and Terenzini, 1991).

Stanford (1992), in his synthesis of the theories of many researchers who studied student development reported that “...one (could) reason that the more contact and/or involvement a college student has with developmental agents through events and experiences, the greater the possibility that development will be influenced" (p. 18). Terenzini, Pascarella, and Blimling (1996), concluded that, based on their research on the Student Learning Imperative from the American College Personnel Association (1994), "students' out-of-class experiences appear to be far more influential in students' academic and intellectual development than many faculty members and academic and student affairs administrators think" (p. 157).

\section{$\underline{\text { Student Development and Co-Curricular Activities }}$}

Calahan and Mabey (1985) listed three different models of student development and leadership on college campuses. First was the traditional student affairs model, 
which focused training on students who were in leadership positions. Second was a more academic model with a focus on interdisciplinary courses to be completed by students. The third was housed in a professional program (i.e., law or medicine) and was designed to prepare students for leadership and involvement within a particular field. For the purposes of this research, the traditional student affairs model will be the focus, as that model harbors the instruction and learning which occurs through participation in cocurricular activities and organizational leadership (McIntire, 1989).

Smitter (1998) described the co-curricular opportunities provided by student affairs professionals as offering the ability to practice community involvement and leadership on campus. In support of the student affairs model, Smitter went on to report:

Involvement opportunities in clubs, organizations, or student government are often housed within the student affairs division and offer students a direct link to leadership opportunities. Receiving information about leadership, then practicing, is crucial to the retention of leadership skills. In addition, students who are involved in clubs and organizations have a direct link to advisors who can work with students individually to develop better leadership skills. These types of opportunities are where students look when they think of leadership on campus. (p. 3)

Barsi, Hand, and Kress (1985) identified five personal traits which all student leaders should possess and which are attainable through the type of involvement Smitter 
(1998) discussed. They included a well developed value system, human relations skills, the ability to be flexible, a sense of insight and perception, and a positive and realistic self-concept. Gulick and Urwick (1937), reported on the major tasks of management: planning, organizing, staffing, directing, coordinating, reporting, and budgeting. A study by Kuh (1995) found that 85 percent of college senior respondents $(n=126)$ reported the perception of having learned those very skills by participating in leadership positions and by being involved while they were in college. Other similar studies (Schuh and Laverty, 1983; Bialek and Lloyd, 1998; LeBard, 1999) have produced comparable results.

\section{Co-Curricular Involvement and Post-Graduate Characteristics}

If student affairs administrators are to plan for and participate in the development of college students, then there is a need to ascertain that the programs which student affairs professionals implement are having the desired effect. If the development of student involvement and leadership opportunities has resulted in the relationship indicated by the literature, then what remains is the continuation of such activity among students after they graduate and enter the workforce. Several studies have been conducted during the last 50 years to determine the relationship between college involvement and leadership positions in the lives of students after they graduate (Bruins, 1985; Burton, 1974; Florestano, 1970; Roskens, 1958; Shandley, 1988; and Sommers, 1991). 


\section{$\underline{\text { Social, Civic and Professional Involvement }}$}

Bruins (1985), in a study of high school students in Scottsdale, Arizona, tried to determine if participation in co-curricular activities in secondary education was related to adult accomplishments. His results indicated that, not only was the level of student activity statistically significant when compared with adult accomplishment, it was actually more statistically significant than academic performance.

In 1970, Florestano administered a leadership opinion survey to male graduates of the University of Maryland in the 1950s. Leaders were defined as having been selected to Who's Who Among Students in American Universities and Colleges and/or members of Omicron Delta Kappa, an honorary leadership fraternity. His results were compared to male students who were not selected for membership in either of those organizations and the results were compared $(n=145)$. The findings indicated that the graduates who were defined as student leaders scored significantly higher in four out of seven participation sub-scales (occupational and professional, social and recreational, fraternal and services, and military).

In a 1974 study, Burton found that those students defined as leaders at the University of Missouri - Rolla Campus during the 1960s were more likely to join charitable, recreational and social fraternal organizations on a local level and political and volunteer organizations on a regional level. These findings, however, were limited only to male graduates. 


\section{Co-Curricular Involvement and Leadership Positions}

Roskens (1958) studied four decades of male graduates $(n=896)$ of the College of Liberal Arts of the University of Iowa. He found a substantial positive correlation between co-curricular activity in college and an active role in community leadership after graduation. His Pearson Correlations scores for the four groups of graduates studied (one group from each decade from the $1920 \mathrm{~s}$ to the $1950 \mathrm{~s}$ ) ranged from $\mathrm{r}=.37$ to $r=.63$. Sommers (1991) also produced results indicating that there was a high positive correlation between participation in college leadership activities and participation in leadership activities after graduation. His population consisted of a random sample of former pre-identified student leaders at the Oregon State University from 1960 to 1985 $(\mathrm{N}=2542, \mathrm{n}=235)$.

\section{Salary}

A relationship which has not been measured frequently in the literature is that between the level of student involvement and leadership in college and salary earned after graduation. Havemann and West (1952) found that male graduates from 1910 to 1940, who had been active in four or more co-curricular activities, earned significantly less than graduates who had not been involved at all. They attributed their findings, however, to the fact that the study examined a period (especially concerning the older graduates) when participation in co-curricular activities was not held in great favor.

Jepson (1951) detected different results from Havemann and West (1952), however, among male graduates of Fresno State College who had graduated 15 years earlier. He found significant differences in salary between students he defined as high in 
extra-curricular participation and those who ranked lowest in participation. Christenson (1969) also reported higher income as one of the long-term personal gains of students who participated in student government, as did Downey, Bosco, and Silver (1984) and Roskens (1958).

\section{Job Satisfaction}

Similar to the findings regarding involvement, leadership, and salary, researchers have also noted a positive correlation between college leadership and involvement and satisfaction in post-graduation employment. Roskens, as early as 1958 , discovered that students who participated in college activities reported an increased level of job satisfaction as well as higher income, though he admitted that such conclusions were neither abundant nor entirely consistent. Downey, Bosco, and Silver (1984) also discovered a significant difference in the perceptions of job satisfaction among student leaders who were involved in student government, while Pascarella and Terenzini (1991) found that college graduates in general reported only modestly more employment satisfaction than people who had never attended college.

\section{Statement of the Problem}

The purpose of this study was to examine if involvement in co-curricular activities in college had a statistically significant relationship when compared to postgraduate involvement, salary received, and perceived intrinsic, extrinsic, and overall job satisfaction. Specifically, were students categorized as involved and who held leadership positions in college more likely to continue such involvement and leadership activity 
upon graduation; were there significant salary differences between the involved and uninvolved populations; and were the involved students more satisfied with their current employment? The study measured the level of student involvement and leadership of 1990 graduates of state-supported four-year colleges in West Virginia (Bluefield State College, Concord College, Fairmont State College, Glenville State College, Shepherd College, West Liberty State College, and West Virginia State College). Ten years was indicated in the literature to be an appropriate amount of time for students to become established in careers and other types of involvement (Burton, 1974; Florestano, 1970; Rokens, 1958; and Sommers, 1991). Based on the responses to the West Virginia College and Community Involvement Survey, respondents were classified as either involved or uninvolved. The categories were then compared to levels of post-collegiate social/civic involvement, professional involvement, leadership positions, salary, and job satisfaction.

\section{Objective of the Study}

The overall objective of the study was to add to the body of knowledge as concerning the value and worth of participation in college activities and leadership positions. Specifically, it attempted to determine if the value of those experiences remained with the student and continued to have an impact after the student graduated. NASPA (1987) assumed that "student involvement enhances learning" and that teaching "effective citizenship" is a role of an institution of higher education (p. 11). McIntire (1989) argued that student affairs professionals should assume the responsibility for the 
development of students and student leadership on campuses. This study, when added to the existing body of knowledge on the effect of college leadership and participation after graduation, will help ascertain if those assumptions and mandates are being met.

\section{Research Questions}

The current literature on the relationship between college involvement and postcollege activities suggested the following research questions, based on the objective of the study:

1. What is the correlation, if any, between co-curricular college involvement and post-graduate involvement in community organizations?

2. What is the correlation, if any, between college co-curricular involvement and post-graduate involvement in professional organizations?

3. What is the correlation, if any, between the college co-curricular involvement and post-graduate leadership positions held in community and professional organizations?

4. What is the correlation, if any, between college co-curricular involvement and post-graduate salary?

5. What is the correlation, if any, between college co-curricular involvement and post-graduate intrinsic, extrinsic, and overall satisfaction with current employment? 


\section{Operational Definitions}

This study will use the following operational definitions:

1. College Involvement: Participation in co-curricular activities, student organizations and leadership endeavors as indicated by responses reported on the West Virginia College and Community Involvement Survey.

2. Post-Graduate Leadership Positions: The involvement of college graduates in elected or appointed positions in social, civic, religious, service, recreational, fraternal, military, and professional organizations as indicated by responses on the West Virginia College and Community Involvement Survey.

3. Job Satisfaction: The levels of self-perceived intrinsic, extrinsic, and total job satisfaction in current employment as indicated by responses reported on the Mohrman-Cooke-Mohrman Job Satisfaction Scale.

4. Professional Involvement: The involvement of college graduates in professional organizations relating to their field of employment, as indicated by responses reported on the West Virginia College and Community Involvement Survey.

5. Salary: Amount of compensation received annually from primary source of employment as indicated by responses reported on the West Virginia College and Community Involvement Survey.

6. Social/Civic Involvement: The involvement of college graduates in social, civic, religious, service, recreational, fraternal and military organizations 
as indicated by responses reported on the West Virginia College and Community Involvement Survey.

\section{Significance of the Study}

Komives, Lucas, and McMahon (1998) reported that, in a rapidly changing world, individual involvement was required to incorporate positive change in a community. Much of the community work that is performed is accomplished through an individual's involvement in social, civic, religious, service, recreational, fraternal and military organizations. Nolin, Chapman, and Chandler (1997), reported that there was a high positive correlation between educational level attained and levels of community participation and political participation and attitudes.

Clark (1985) argued that earlier colleges gave much more attention to a curricular model of leadership than present-day institutions. He acknowledged, however, that college graduates today would be called upon in greater numbers than ever before to participate in and to lead the actions of groups, both in a profession and in the community. Caruso (1981) found that such involvement in professional and community organizations led to an increase in employee productivity as well as an increase in a person's contribution to society and personal, physical, and mental well-being. Clark (1985) attributed such involvement to the maintaining of high ideals for one's society and for one's own conduct. This involvement contributes to the common good in addition to building desirable life skills and continuing educational endeavors for participants. Ellis (2000) listed over 45 motivations for people to be involved and hold 
leadership positions in professional organizations and in social and civic organizations. They included the sharing of a skill, the performance of a civic duty, the donation of professional skills, the utilization of varying skills, the ability to be an agent of change, and the opportunity to test oneself in new situations.

Nolin, Chapman, and Chandler (1997) found a correlation between educational attainment and extent of involvement and leadership, while McIntire (1989) argued that the leadership skills and involvement opportunities undertaken during a college education were a mandate of the student affairs division. NASPA (1987) and Striffolino and Saunders (1989) reinforced that argument. McIntire (1989) and Smitter (1998) espoused the use of the student affairs model in the dissemination of involvement and leadership opportunities on college campuses and offered that student affairs professionals were in the best position to deliver those experiences. Given these facts, the implications for student affairs professionals are obvious.

Gulick and Urwick (1937) reported on the major tasks of management: planning, organizing, staffing, directing, coordinating, reporting, and budgeting. With regard to student affairs professionals, this study will have implications in each of these areas. If research continues to show that student development and involvement has a statistically significant relationship on the involvement and leadership participation of students after they graduate, then higher education institutions must continue to plan for such development. Furthermore, such findings will encourage institutions of higher education to organize departments with appropriate staffing to reach such ends. These efforts must also be directed and coordinated as part of the role and function of the mission of 
student affairs. Such endeavors must also allocate appropriate budgeting to support such activities. The results of the activities are then reported as part of the function of the institution as a whole and assists the higher education institution in educating leaders for society.

This study was significant in several ways when compared to the similar investigations which have been completed. The research completed prior to 1974 (Burton, 1974; Florestano, 1970; and Rokens, 1958) measured only male students. All of the previous studies mentioned in this research examined graduates of only one institution (Burton, 1974; Florestano, 1970; Rokens, 1958; and Sommers, 1991). Additionally, many of these inquiries measured only samples of students who were preidentified as leaders with questionnaire responses measured against an established norm and statistical information on college graduates (Burton, 1974; Florestano, 1970; and Rokens, 1958).

This study will be different from most previous studies in three ways. First, it will provide data from a total of seven institutions across West Virginia. Second, respondents will be both male and female. Finally, the original and sample populations will contain students classified as both involved and uninvolved.

\section{Limitations of the Study}

This study has the following limitations:

1. The reliability and validity of the research instrument, the West Virginia College and Community Involvement Survey, could impose a limitation on the results of this study (Kerlinger and Lee, 2000). 
2. It is assumed that the respondents in this study will complete the survey instrument accurately (Kerlinger and Lee, 2000).

3. A potential limitation with any survey instrument is that "the survey process itself can temporarily lift the respondent out of his or her own social context, which may make the results of the survey invalid" (Kerlinger and Lee, 2000, p. 614).

4. Study results will contain information concerning students who graduated from four-year state colleges in West Virginia thereby limiting generalization to other populations.

5. Potential sources of invalidity are questionable as related by Gay (1996) when conducting causal-comparative research.

6. This study assumed that graduates of the Class of 1990, showing a ten year interval as indicated by other researchers, will have had sufficient time to establish themselves personally and professionally and will have had ample time to become involved in organizations and leadership opportunities (Burton, 1974; Florestano, 1970; Rokens, 1958; and Sommers, 1991).

7. This study assumed that the sample population would be representative of the demographic population of college students in West Virginia.

Deviations from a representative population (e.g., sex or age of respondents) could affect the results. 


\section{Chapter Two}

\section{Review of the Literature}

During the past century, a litany of researchers espoused a plethora of benefits for students of higher education who became involved in co-curricular activities and took advantage of leadership opportunities on campus. The outcomes of such involvement have been listed by many prominent investigators in the field. Falvey (1952) found that participation in campus governance led to valuable citizenship training, development of responsibility and communication skills, practical experience in policy-making, and personal development in both leaders and followers. Rudolph (1962) saw the same participation as an arena where students could develop organizational and life skills, as well as develop a sense of character. Sanford (1966) described colleges as developmental communities. Astin (1978) associated participation in student government with increased political liberalism, hedonism, and artistic interests.

Other researchers and theorists have discovered similar effects of participation and leadership. Student involvement has been linked to interpersonal skills development, civic education, and working effectively within organizations (Morrell and Morrell, 1986), cultural awareness, social concerns, and personal capabilities (PowerRoss, 1980), skills that will result in long-term vocational, social, and personal gains (Christenson, 1969), and proficiencies in decision-making, administrative skills, budgeting and accounting, and bureaucratic and programming abilities (Berman, 1978). Kuh (1995) noted that $85 \%$ of responding college students reported college participation 
and leadership positions assisted those students in the tasks of planning, organizing, managing, and decision-making. Minihan (1957) and Bass (1981) both promoted cocurricular activities as a means of student development. Most researchers have agreed that student learning and development in college is positively influenced by the level of student involvement (Astin, 1984; Astin, 1993; Astin, et al., 1994; Kuh, 1993a; Kuh, 1993b; Niles, Sowa, and Ladden, 1994).

Terenzini, Pascarella, and Blimling (1996) advanced four conclusions about the effect of out-of-class experiences on the cognitive development of a college student. First, out-of class experiences are more influential on development than people think. Second, not all of these experiences are positive (in their research, living at home, fraternity/sorority involvement, athletics, and working in an off-campus employment setting were found to have a less than positive impacts). Third, programs in student affairs needed to better capitalize on student learning outcomes and the utilization of cocurricular experiences. Finally, in cases where co-curricular associations were found to have a positive impact, there were definite opportunities for active student involvement. This involvement was defined by Astin (1984) as the amount of physical and psychological energy that a student devoted to the academic experience, both curricular and co-curricular.

In the early years of the development of institutions of higher education, there was a greater curricular focus on leadership issues (Clark, 1985). As higher education continued to expand, however, fewer and fewer programs offered course sequences in preparing students to lead group actions. During the 1920s - 1930s, there was a 
resurgence in the philosophy of the development of the "whole" student and the promotion of two specific domains of development: cognitive/academic and affective (Terenzini, Pascarella, and Blimling, 1996). The foundations for this philosophy came, not as much from institutional faculty, as from staff who were hired to address student issues. McMillon (1997) found that these staff members have continued to be the initiators, planners, and evaluators of co-curricular and leadership programming. He reported that the number of colleges with development programs grew from $43.5 \%$ to $74 \%$ from the mid-1970s to the mid-1990s.

McIntire (1989) maintained that it was time for student affairs administrators to assume an appropriate role as equal partners in the educational establishment and that these same administrators should assume the responsibility for student development and leadership development on campus. The development of active citizens and student leaders has often been cited as an important need for colleges (Newton, 1975). Student development was noted by Barsi, Hand, and Kress (1985), to be absolutely necessary for an institution to produce effective leaders. Striffolino and Saunders (1989) encouraged student affairs professionals to take an active and aggressive role in the development of students, not only as scholars, but as citizens as well. According to Striffolino and Saunders, "Today's higher education milieu demands that student affairs professionals take active and aggressive leadership in assisting students to develop their full potential - both as scholars and as citizens" $(1989$, p. 51). If it is a basic proposition that human development is an organizing purpose for higher education (Chickering and Reisser, 1993), and colleges and universities are charged with producing leaders (McIntyre, 
1989), then the significance of providing opportunities for student involvement and leadership development is apparent.

Pascarella, Ethington, and Smart (1988) imparted that one of the primary goals of higher education in America has been the development of a person's moral and civic responsibility and that colleges, as institutions, should prepare a person for concerned and involved citizenship in a democracy. The development of involvement and leadership in students was found by Chambers (1992) and The Education Commission of the States (1986) to be critical for the preparation of citizens and participation in community and civic organizations.

To understand why and how colleges and universities should promote the attributes of student development, leadership, and involvement, the fundamental principles of involvement and leadership theory must be addressed. Blume and Schwartz (1994) reported that leadership, especially in the realm of student development, was not necessarily based on the holding of a title or an office. They reported that leadership roles were much more subtle. Based on their definition, students who were considered involved on a campus, though not in an elected or appointed position, were seen as leaders in terms of the general student population.

\section{A Synopsis of Involvement and Leadership}

There was little empirical knowledge of leadership prior to 1900 (Kreck, Crutchfield, and Ballackey, 1962). Prior to 1930, there was little history of inquiry regarding leadership abilities, theories in leadership, and the attributes and distinctions of varying types of leaders. Some of the earliest research was performed by Terman in 
1904 (Florestano, 1971). Much of the foundation for the development of leadership theory was established by a study conducted by Lewin, Lippitt and White in 1939. In the aforementioned study, aggressive behavioral patterns were examined, out of which arose a research focus on the personality characteristics and qualities of a leader. This was determined to be the trait approach or Trait Theory. Burton (1974) commented that the trait approach was one of the earliest used in attempting to study leadership. Students of trait theory believed that a leader could be identified as possessing certain traits. Bass (1981) considered Trait Theory research during the first half of the last century to be devoted to the effects of democratic and autocratic approaches to leadership. Stogdill (1948) and Gibb (1954) both performed research on the Trait Theory approach. Stogdill determined that the traits of a leader were not valid measures in determining the social interactions between leaders and followers. Gibb, discussing similar results, found that studies on Trait Theory failed to find consistent patterns of traits by which to characterize leaders.

Walsh (1970) described the period ushering in the second era of leadership study as the situational or behavior period or the "times make the man" approach, as leaders emerged based on the specific needs of a particular time. In Charismatic Theory, leadership is derived as a result of special personal qualities that attract followers. Over this period, Lewin, Lippitt and White's (1939) work evolved into the style perspective, out of which emerged four general theories of leadership: Universal Trait, Universal Behavior, Situational Trait, and Situational Behavior (Behling and Rauch, 1985). These theories are listed chronologically in order of their development (Burton, 1974). Many 
of the elements and theories of leadership are rooted in these foundations, although the definitions and number of theories have grown significantly over the years (Doherty, 1995).

By the late 1960s to the early 1970s, and as previously noted by Burton (1974), writers in the field began to view leadership as a mix of Trait Theory and Situational Theory (Contingency Theory). Walsh (1970) called this trait-situational approach, whereby people possessing certain traits aspire to leadership positions in specific situations. Even Stogdill (1974), by this time, changed perspectives on the idea of leadership and developed 11 classifications of leadership. His classifications were listed as: (a) a focus of group processes; (b) effects of personality; (c) the art of inducing compliance; (d) the exercise of influence; (e) an act of behavior; (f) a form of persuasion; (g) a power relation; (h) an instrument of goal achievement; (i) an emerging effect of interaction; (j) a differentiated role; and (k) an initiation of structure. Bass (1981) described how these classifications were interwoven into many of the various leadership theories.

In 1978, Burns proposed the Theory of Transformational Leadership. This theory was a mix of Human Development Theory (Erikson, 1963), The Hierarchy of Needs Theory (Maslow, 1968), and the Theory of Cognitive Moral Development (Kohlberg, 1969). The Theory of Transformational Leadership marked the beginning of examining leadership by looking at the characteristics of the followers. Blume and Schwartz (1994) explained that the traditional paradigms were replaced by mutually interdependent relationships between leaders and followers and were marked by roles that were 
dynamic and somewhat ambiguous. During this time, leadership became administration by consensus and by transaction. The idea of servant leadership, as defined by Robert K. Greenleaf, began to emerge.

Bowman (1997) discussed the continued development of leadership theory over the last decade of the 1900s, and that much of the theory (which she described as Contemporary Leadership Theory) development was now written in a pragmatic and popular style for general readers outside of academe. She suggested that the newer theories had three recurring themes. First, there was a servant-leader paradigm in which leaders must shift their focus from their own needs to the needs of their followers. The second involved a spiritual-ethical orientation and the premise that more attention focused on character, integrity, trust, and honesty would result in happier, and thereby more productive, followers. Finally, the empowerment of followers and the building of teams and collaboration to accomplish organizational objectives created credibility within the followers and helped achieve organizational goals. Peter Block (1993) defined this new approach as leadership by stewardship and suggested that the new leaders were not motivated by what could be obtained from leadership positions, but by what the leaders can provide for the followers. The theories and applications related to leadership, leadership development, and the involvement of members of a community or organization are applicable not only in work environments, but also with regard to social, civic, and professional involvement and leadership in the community (Bowman, 1997). Over time, society's understanding of involvement and leadership and how these concepts function in contemporary organizations has been influenced by the integration 
of many of the theories discussed earlier (Komives, Lucas, and McMahon, 1998).

Johnson (2000), related how the work of Komives, Lucas, and McMahon is directed toward college students and their development as involved and informed citizens and competent leaders.

Barsi, Hand, and Kress (1985) began to show this trend when searching for potential student leaders with human relations skills, flexibility, insight, and selfconcept. Spears (2001) described how the attitude of servant-leadership is seen as the ethical basis for many of the programs in student development. As students in college seek and discover experiences to help instill leadership skills and assist them in working in and with groups of people, Johnson (2000) reminds people how important that involvement is.

\section{The Need for Involvement}

P.L. Benson (1993) symbolized an urgent need when he exclaimed that "It is unlikely that any society can thrive unless citizens are able and willing to sacrifice personal gain for the common good" ( p. 34). Blume and Schwartz (1992) explained that today's society needed change, which could only come about through the involvement and leadership of participants in higher education. Nolin, Chapman, and Chandler (1997) responded to one of the National Education Goals. The goal stated that students in American schools should learn to use their minds well, so that they may be prepared for responsible citizenship. In a study to illustrate that goal, Nolin, Chapman, and Chandler found that: (a) $59 \%$ of adults belonged to a community or professional organization; (b) younger adults were as likely as older adults to participate in 
community events; and (c) adults with a higher level of educational attainment were more likely to participate in community service organizations.

Paul (1992) advanced that a guiding principle of student development theory was the education of students regarding the responsibility for self-development and for community contributions. Paul's goal was to teach students to use influence to effect desirable change in the community and in organizations. The Pew Partnership for Civic Change (1997) gave responsibility for the sustainment of communities to the work done by members of those communities. Calhoun (1993) indicated that participation in civic activities gave young people a chance to be productive citizens and achieve a civic ethic as well as a personal maturity. Perkins and Miller (2000) added that providing people with opportunities to serve enabled those people to become contributors, problem solvers and partners in improving communities and the larger society.

People have volunteered in the community and in professional organizations for a multitude of reasons. These have included: (a) to feel needed; (b) to share a skill; (c) to donate professional skills; (d) to gain leadership skills; (e) to do a civic duty; and (f) because of satisfaction from accomplishment. In this vein, not only did volunteers and those who became involved in community actions provide a service, they were gaining benefits as well (Ellis, 2000). Perkins and Miller (1992) stated that communities foster and encourage healthy development by involving all people, thereby creating a sense of belonging and shared purpose. They indicated that a primary path to achieve that goal was through participation and leadership in civic organizations. Perkins and Miller also associated such involvement with furthering a person's (a) intellectual development, (b) 
social development, (c) psychological development, and (d) political efficacy and citizenship.

According to Watts (1988), community involvement, including the holding of leadership positions, and the provision of educational opportunities toward that end, was critical for the development of both individuals and communities. Graham and Cockriel (1995) correlated that, critical to individual and community development, was the need for institutions of higher education to address the personal development needs of students. Graham and Cockriel's research indicated that involvement and leadership in college contributed to intra-personal development, personal valuing and moral development, community leadership and development, and civic involvement and awareness.

One place where people experience the opportunity for involvement and the development of leadership skills is during the completion of college coursework (Kuh, 1995). Chickering and Reisser (1993) described that period as a time when students could not only learn the theories of development, community, and leadership in the classroom, but could put those theories into practice through participation in cocurricular activities. Kuh explained that a multitude of benefits, including social competence, autonomy, self-confidence, and an appreciation for human diversity, were the result of such involvement. Involvement in co-curricular activities was found by Bialek and Groves (1998) to have historically enhanced leadership development and skills. The student affairs model of training college students in areas of leadership and interaction, whereby students are provided training through practical experience and 
instruction while participating in co-curricular activities, has been the dominant force in preparing these students (McIntire, 1989). It is therefore important to understand the development of these types of activities on college campuses.

\section{The Evolution of Co-Curricular Activities in College}

The evolution and belief in the value of co-curricular activities parallels the values placed on recreational and leisure activity throughout American culture. The influence of the Puritan movement and the ideals of that society are important to remember in the earliest period of American higher education. The earliest campaign to establish institutions of higher education in pre-revolutionary America was inaugurated, propelled, and financed by churches with strong puritanical convictions (National Association of Student Personnel Administrators, 1987). The establishment of a new nation and the survival of people were of paramount importance. Inactivity, or activities performed other than those leading to immediate productive gain, were both culturally improper and, in many cases, illegal. Youth, during that period, were impressed by their educators with the earnestness of life (Frederick, 1959).

Lucas (1996) documented the origins of what is called student life as beginning in the period just after the Revolutionary War. In the early 1800 s, as the foundation for America was laid, there was a call for revisions in the college curriculum with an increase in the levels of political, economic, social, intellectual, and personal freedom. During this period, literary societies became popular (Street, 1997). The literary society was the bastion of the student life program until the period around the Civil War.

In 1815, the first college union was formed at Cambridge University in England. It was literally a union of three debating societies which built a common building for 
living quarters, debating, offices, and activities (Association of College Unions International, 1982). In an effort to purport similar ideals, the first college union in America was established by Harvard in 1832, specifically for debating purposes. The first of what could be called a modern student union, with lounges, dining rooms, an auditorium and cafeteria, however, did not appear until 1896, at the University of Pennsylvania.

During this period after the Civil War, significant changes in higher education led to the emergence of student affairs work. The character of higher education institutions evolved from a homogeneous demographic with a curriculum based on religious foundations to an objective of educating a responsible and enlightened citizenship as well as vocational training (NASPA, 1987). Prior to this period of change, the concept of in loco parentis (in the place of the parents) had been the guiding relationship between higher education institutions and students since $17^{\text {th }}$ Century England (Altbach, 1974; Lucas, 1996; Sommers, 1991). During the later 1800s, however, the dominance of the debate and literary societies was replaced by growth and interest in social fraternities and intercollegiate athletics (Brubacher and Rudy, 1974; Lucas, 1996). Lucas described how the fraternal movement “... grew out of a desire to bring students together for no other purpose than to enhance sociability among groups of highly selective peers" (p. 346). Brubacher and Rudy also reviewed a fundamental shift in thinking during this time from in loco parentis to a more German influenced laissezfaire attitude toward student life outside the classroom. One reason for this change was a changing dynamic among American faculty, many of whom were pursuing graduate 
work in Germany where this more relaxed attitude toward students' activities outside the classroom was prevalent (Brubacher and Rudy, 1974; Falvey, 1952; NASPA, 1987;

Rudolph, 1962). Frederick (1959) described this as a period during which suppression was not promoted. The rules were simply relaxed, primarily at the insistence of the students. NASPA (1987) attributed much of the broadening of higher education institutions in this period after the Civil War to (a) a rapidly growing population, (b) industrial growth, and (c) federal legislation which dramatically altered access to higher education and changed its nature and purpose. Much of this legislation was rooted in the Morrill Act of 1962, the Hatch Act of 1887, and the second Morrill Act of 1890 (Williams, 1991). These acts effectively opened the doors of higher education to the masses and gave post-secondary education a greater vocational focus.

According to NASPA publications (1987), the response of institutional presidents to this emerging phenomena was to appoint persons to handle matters regarding student problems and discipline. Other managers were appointed to what was being called the administration, including student activities advisors, as students began to look toward each other for social and intellectual stimulation (Chickering and Reisser, 1993). Another, and arguably the greatest renaissance in this area, occurred generally after World War II with the passage of the G.I. Bill and the tremendous influx of students into the higher education system because of the increased financial assistance available (Trow, 1997).

With the aforementioned paradigm in place, academe entered into a period which Frederick (1959) termed the period of exploitation. This period was viewed by Frederick 
rather negatively and was seen as a time when the motivating factor for student involvement was the production of some benefit to an institution, teacher, coach, or administrator. Several years later, however, "exploitation" began to be viewed as using co-curricular activities to foster student development outside the classroom and allow for the personal development of the student and the application of learned skills outside the classroom (Astin, 1977; Chickering, 1981; Chickering and Reisser, 1993). With the realization that co-curricular activities led to the personal growth of students (Bass, 1981; Miller and Jones, 1980; Morrell and Morrell, 1986; Newton and Ender, 1978), interest in the social and emotional growth of students became a concern of many institutions of higher education.

\section{The Emergence of of Student Development}

With the advent of the realization that co-curricular activities led to the development of students as individuals, increased retention, and enhanced graduation rates (Morrell and Morrell, 1986), came an increase in the interest of purposefully developing these qualities and experiences for students (Chickering and Reisser, 1993). Yoakum (1919) traced the beginnings of the movement to psychological testing that was performed during World War I. This paradigm continued to emerge in the 1920s and 1930s. However, many researchers set the benchmark of this movement as 1937 , with the publication of the Student Personnel Point of View (American Council on Education, 1937; NASPA, 1987). This document was sponsored by the American Council on Education and placed a great deal of influence on the responsibility of an institution of higher education in educating students not only in a vocation, but to address the need for 
students to develop as individuals. Jackson (1978) described student development as the application of human development theory to college students.

Historically, the period of evolution for student development through the 1920 s and 1930s was marked by a division of labor in higher education institutions (Terenzini, Pascarella, and Blimling, 1996). Faculty became charged with the cognitive, or academic, growth of college students. By contrast, student affairs administrators became responsible for a student's affective growth. The American College Personnel Association (1994), discussed the impact of this cumulative effect in The Student Learning Imperative. According to the ACPA, there was a need for the definitive lines between academics and student affairs to be blurred in an effort to reach both the cognitive and affective domains concurrently, thus educating the "whole" student. Stanford (1992), in discussing the development of traditional-aged college students (1824), defined student development as a process through which students grew, developed and matured, both psychologically and psycho-socially.

As colleges and universities began to apply human development theory to college students, speculations began to appear to explain the foundations behind student development. One of the first and most popular theorists, A.W. Chickering (1969), proposed seven vectors through which college students passed in an educational journey. The stages were: (a) developing competence; (b) managing emotions; (c) developing autonomy; (d) establishing identity; (e) freeing interpersonal relationships; (f) developing purpose; and (g) developing integrity. According to Chickering, each step 
built upon the previous, and similar to reaching the top of Maslow's Hierarchy of Needs (Maslow, 1968) and Covey's Seven Habits of Highly Effective People (Covey, 1989), one must have completed a step before progressing to the next. Criticism of this theory came in the form of generalizing such rigid steps to a global population. However, in a 1996 qualitative study, Sermershem obtained data from Greek leaders, $95 \%$ of whom reported their Greek experience to be very to extremely beneficial with regard to Chickering's stages.

In attempting to explain college student development and the reaction of institutions of higher education to that development, Astin (1984) identified three implicit pedagogical theories, which appeared over the years in the chronological order listed here. First, was the Subject-Matter Theory. This theory was popular among faculty members. According to Subject-Matter Theory, student learning and development was a simple matter of exposure to academics. A weakness of this theory was the assignment of a passive learning role to the student.

The second theory identified by Astin was the Resource Theory (Astin, 1984). According to Resource Theory, which was popular among administrators, the bringing together of physical resources (i.e., buildings and faculty/student ratios) is the primary component in the educational experience. Third, was the Individualized, or Eclectic Theory. According to Astin, this theory, popular among developmentalists, tried to meet the needs of individual students on a case-by-case basis. The obvious weakness to this theory was the amount of financial and human resources required. 
Astin combined traits from these theories in 1984 and proposed a Theory of Student Involvement. Astin's theory brought together the classroom experiences of Subject-Matter Theory, the foundations of Resource Theory, and the individualized attention of Eclectic Theory. The resulting theory was the beginning of the call to blend the lines between classroom and out-of-class experiences for college students.

Ten years later, Kuh (1995) expanded on Astin's (1984) Theory of Involvement. Kuh defined involvement as the expenditure of both psychological and physical energy, whether that energy is specific (leading) or general (following). Kuh then asserted four propositions that must be considered for Astin's Involvement Theory. First, was the realization that different students exert varying amounts of energy in different activities. Second, was that student involvement possessed inherent features that were both quantitative and qualitative. Third, the benefits derived from involvement were a function of both the qualitative and quantitative functions. Finally, Kuh advanced that the effectiveness of educational policy or practice was related to the extent to which it encouraged students to take initiative and become active on campus.

Chickering and Reisser (1993) introduced eight key elements to what they believed influenced the development of students. The theories were: (a) a clear and consistent institutional mission; (b) institutional size; (c) student-faculty relationships; (d) curriculum; (e) teaching; (f) friendships and student communities; (g) student development programs and services; and (h) creating an educationally powerful environment. 
During the 1960s to 1990 s, research into the area of student development reached a heightened popularity with a resulting profusion of theories on how and why college students develop as they do. Pascarella and Terenzini (1991) wrote what was considered to be the definitive work on student development theory (Chickering and Reisser, 1993). They grouped the varying student development theories into four main categories. Psychosocial theories reported that students developed through a series of stages or tasks that progressed from one to the next. Cognitive theories revealed how students developed thinking skills and the evolution of their frames of reference. Typology theories provided for development in terms of an individual's learning style or personality type or socioeconomic background. Person-environment interaction theories focused on the combination of individual characteristics with environmental influences and the resulting effect on the development of an individual (Pascarella and Terenzini, 1991).

Stanford (1992), in his synthesis of the theories of many researchers who studied student development deduced that “...one (could) reason that the more contact and/or involvement a college student has with developmental agents through events and experiences, the greater the possibility that development will be influenced" (p. 18). Stanford's thoughts resembled those of Kuh (1994) in defining involvement. Terenzini, Pascarella, and Blimling (1996), concluded that, based on research on the Student Learning Imperative from the APCA (1994), “students' out-of-class experiences appear to be far more influential in students' academic and intellectual development than many faculty members and academic and student affairs administrators think" (p. 157). 


\section{$\underline{\text { Student Development and Co-Curricular Activities }}$}

Calahan and Mabey (1985) listed three different models of student development and leadership on college campuses. First was the traditional student affairs model, which focused training on students who were in leadership positions. Second was a more academic model with a focus on interdisciplinary courses to be completed by students. The third was housed in a professional program (i.e., law or medicine) and was designed to prepare students for leadership and involvement within a particular field.

Smitter (1998) described the co-curricular opportunities provided by student affairs professionals as offering the ability to practice community involvement and leadership on campus. Citing two specific advantages, Smitter reported that: (a) programs in student affairs were inclusive to the campus community and would not be confused by being limited within or housed by a specific discipline; and (b) student affairs professions were versed and possessed an expertise in student development theory. In continued support of the student affairs model, Smitter went on to report:

Involvement opportunities in clubs, organizations, or student government are often housed within the student affairs division and offer students a direct link to leadership opportunities. Receiving information about leadership, then practicing, is crucial to the retention of leadership skills. In addition, students who are involved in clubs and organizations have a direct link to advisors who can work with students individually to develop better leadership skills. These types of opportunities are where students look when they think of leadership on campus. (p. 3) 
When discussing involvement, Street (1997) described the student organization as a facet of the campus environment that appeared to offer one of the best opportunities for involvement. Street's writings, however, made two important assumptions. First, student organizations, while beneficial to student involvement, were also an important resource for the institution. Secondly, student organizations played an important role in student development and satisfaction. In an earlier 1992 study, Stanford made a similar assumption that co-curricular involvement affected the levels of student development. Stanford concluded through research that "relationships do exist within organizational and non-organizational involvement and areas of student development among student leaders" (p. 23).

Twale (1988) asserted that student activities (primarily co-curricular activities housed within a student affairs model) provided three related objectives to assist in the development of students. First, such activities provided physical, emotional, psychological, and intellectual forums to facilitate development. Second, involvement allowed the identification of cognitive skills and affective learning patterns as measurable goals. Finally, co-curricular involvement motivated and developed faculty and staff to become capable of fulfilling the first two objectives while serving as positive role models for students.

Barsi, Hand, and Kress (1985) identified five personal traits which all student leaders should possess and which are attainable through the types of involvement Smitter (1998), Street (1997), and Twale (1988) discussed. They included a well 
developed value system, human relations skills, the ability to be flexible, a sense of insight and perception, and a positive and realistic self-concept. Gulick and Urwick (1937), reported on the major tasks of management: planning, organizing, staffing, directing, coordinating, reporting, and budgeting. A study by Kuh (1995) found that $85 \%$ of college seniors responding to a survey $(n=126)$ reported having learned those very skills by participating in leadership positions and by being involved while they were in college. Other similar studies (Schuh and Laverty, 1983; Bialek and Lloyd, 1998; LeBard, 1999) have produced comparable results.

In referring to student development through co-curricular activities (housed primarily in the student affairs model), Terenzini, Pascarella, and Blimling (1996) described out-of-class experiences as "structured and unstructured activities or conditions that are not directly part of an institution's formal, course-related, instructional process." (p. 150). The most powerful source of influence on student learning was, in the opinion of Terenzini, Pascarella, and Blimling, a student's interpersonal interactions, whether with peers, staff, or faculty. Through such involvement, the students were exposed to new value systems and ideas.

\section{Co-Curricular Involvement and Post-Graduate Characteristics}

Several studies have been conducted during the last 50 years to determine the relationship between co-curricular involvement and leadership positions on the lives of students after they graduate, including studies on social, civic, and professional involvement, the holding of leadership positions, salary, and job satisfaction (Auble and 
Auble, 1953; Bruins, 1985; Burton, 1974; Florestano, 1970; Roskens, 1958; Shandley, 1988; and Sommers, 1991). Student involvement in co-curricular activities in college has been linked to social competence, autonomy, confidence, self-awareness, and appreciation for human diversity (Kuh, 1995), group processes, decision-making, organizational and administrative skill, budgeting and accounting (Berman, 1978), decreases in prejudice and increases in political and social concerns (Loeb and Magee, 1992), and Pascarella, Ethington, and Smart (1988) reported a significant increase in humanitarian values. Other researchers have produced similar results. Pascarella and Terenzini (1991) linked student involvement to an increase in aesthetic interests, altruism, civic responsibility and social consciousness. Sawyer (1999) found that involved students reported a higher level of growth and development. Whitt (1994) discovered that students who reported higher levels of involvement also reported significant levels of social and political awareness and improved communication skills. Kuh and Lund (1994) added an increase in practical competence to the abundance of benefits earned by involved students. Not just limited to traditional students, a recent study by Graham and Gisi (2000) as well as a study performed by Kasworm (1990) reported significantly higher learning outcomes reported by adult students who participated in co-curricular activities.

In a 1974 study of secondary education students, Munday and Davis found that the only factor truly successful in predicting the success of graduates (with even greater reliability than academic performance) was involvement in co-curricular activities. Calhoon and Reddy (1965) and Bruins (1985) also reported similar results. Minihan 
(1957) compared the co-curricular experience at the University of Wisconsin to instances of post-college involvement in citizenship activities. The study examined former student leaders from 1926-1950, with results indicating that the former student leaders were significantly more involved. The respondents to the survey also identified student involvement as the most important motivator for community involvement. Congruent results were achieved by the Human Resources Study Group of AT\&T (1984) in a study concerning managerial performance and progress for over 2000 graduates who were active on campus. The results indicated that, next to a student's chosen field in an undergraduate major, the second best predictor of performance was a student's level of involvement in co-curricular activities. Similar studies have compared the level of a student's co-curricular involvement with post-college factors such as social, civic, and professional involvement, number of leadership positions held, post-graduate salary figures, and job satisfaction.

\section{Community and Professional Involvement}

One of the more recent studies to determine the confidence of the relationship between co-curricular involvement post-graduate characteristics was performed by Swenson (1983). His follow-up study of student leaders from three prominent universities, graduating between 1956 and 1981, targeted student government officers, committee chairs, club presidents, residence hall officers and Greek officers. Of the 200 respondents to the survey, $81 \%$ earned higher than the average salary of a college graduate, $100 \%$ reported a significant degree of satisfaction with employment, and the entire sample perceived that the credit for their participation in civic activities was 
attributable to involvement in co-curricular activities while enrolled in college. A weakness observed in Swenson's work, however, was the lack of a control group of nonparticipants against which to compare the data.

Bruins (1985), in a study of high school students in Scottsdale, Arizona, tried to determine if participation in co-curricular activities in secondary education was related to adult accomplishments. His results indicated that, not only was the level of student activity statistically significant in predicting adult accomplishment, it was actually a better predictor than academic performance.

In a 1974 study, Burton found that those students defined as leaders at the University of Missouri - Rolla Campus during the 1960s were more likely to join charitable, recreational and social fraternal organizations on a local level and political and volunteer organizations on a regional level. These findings, however, were limited only to male graduates.

Schultz and Garrett (1965) surveyed over 4000 alumni of Phi Theta Kappa, a national junior college honorary. The returned surveys indicated that $95 \%$ of Phi Theta Kappa alumni became active in business and professional organizations. Alternatively, Kraft (1951), in a 10-year follow-up study of college graduates, noted that most respondents who were active in college later became involved in civic or social activities after graduation.

Other notable studies related to co-curricular involvement in college and subsequent community involvement after graduation included Bennett (1956) and Holloway (1998). Students involved in co-curricular activities, Bennett concluded, were 
$50 \%$ more likely to assume leadership positions in community affairs. Holloway, 40

years later, in a study of college student government association members, discovered a significant positive relationship between student development and leadership activities and post-graduation involvement in civic and community-based groups. Sermersheim (1996), in a study of Greek leaders on college campuses, noted that the intrinsic rewards of participating in service projects were the catalysts for encouraging similar types of involvement after graduation.

Increases in levels of participation in social, civic, and professional organizations have not been the only areas indicative of increased levels of participation. Researchers have also discovered that students who were involved in or held specific leadership roles while participating in co-curricular activities, have continued to aspire to positions of leadership in later life.

\section{Co-Curricular Involvement and Leadership Positions}

Kuh (1995), reporting from research results, distinguished that leadership experiences as an out-of-class encounter were reported most frequently as an instrument in the development of college students. Researchers including Holloway (1998), LaBard (1999), Sommers (1991), and Roskens (1958), substantiated Kuh's declarations.

LaBard (1999) was particularly interested in community college students and ascertaining if the involvement trends attributed to students of four-year institutions were applicable to two-year students as well. Research conducted on involved students at a two-year campus indicated that, on two-year as well as four-year campuses, students' perceptions of their leadership abilities were positively correlated to the level of participation in school events. 
Sommers (1991) also produced results indicating a high positive correlation between participation in college leadership activities and participation in leadership activities after graduation. His population consisted of a random sample of former preidentified student leaders at the Oregon State University from 1960 to 1985 ( N =2542, n $=235$ ). Sommers' study, however, possessed a weakness similar to Swenson (1983) in that a control group of non-leaders was not selected for comparative purposes.

Roskens (1958), in an early study quoted often in the literature, studied four decades of male graduates $(n=896)$ of the College of Liberal Arts of the University of Iowa. He found a substantial correlation between co-curricular activity in college and an active role in community leadership after graduation. His Pearson Correlations for the four groups of graduates studied (one group from each decade from the 1920s to the 1950s) ranged from $r=.37$ to $r=.63$. Roskens concluded that a significant relationship existed between leadership positions undertaken in college and similar post-graduate participation.

In 1970, Florestano administered a leadership opinion survey to male graduates of the University of Maryland from the 1950s. Leaders were defined as having been selected to Who's Who Among Students in American Universities and Colleges and/or members of Omicron Delta Kappa, an honorary leadership fraternity. His results were compared to male students who were not selected for membership in either of those organizations and the results were compared $(n=145)$. His findings indicated that the graduates who were defined as student leaders scored significantly higher in four out of seven participation sub-scales (occupational and professional, social and recreational, 
fraternal and services, and military). While the study found a positive correlation between involvement and post-graduate leadership, Florestano's results were not of a magnitude by which to determine the relationship as causal.

\section{$\underline{\text { Salary }}$}

A relationship which was not measured frequently in the literature was that between the level of student involvement and leadership in college and salary earned after graduation. Much of the research conducted in this area was performed earlier in the $20^{\text {th }}$ century.

One of the original studies on co-curricular involvement and the statistical relationship with professional salary was conducted by Bridgman (1930). Bridgman studied a group of supervisors and executives at Bell Telephone using college involvement and the association of such involvement to professional success, using salary as a criterion for success. Levels of college activity were ranked by executives and managers as substantial, some, or none. Forty-three percent of those indicating a substantial level of college involvement also indicated a salary in the top one-third of the group. Commensurately, only $28 \%$ of those indicating no college involvement placed in the same salary range. Thirty-eight percent of those reporting no involvement also reported receiving the lowest one-third in salary, compared with $24 \%$ of respondents who had listed substantial college involvement. Krumboltz (1957) performed a chi square statistical analysis on Bridgman's data, as Bridgmen had performed no test of significance. Krumboltz's results of the analysis indicated that the relationship as reported in Bridgman's study was statistically significant. 
Havemann and West (1952) found that male graduates from 1910 to 1940, who had been active in four or more co-curricular activities, earned significantly less than graduates who had not been involved at all. They attributed their findings, however, to the fact that the study examined a period (especially concerning the older graduates) when participation in co-curricular activities was not held in great favor. Gambrill, in a 1939 study, however, found differing results from Havemann and West. Utilizing data on involved students from six college yearbooks, Gambrill demonstrated a significant positive correlation between level of collegiate involvement and annual income.

Jepson (1951) detected similar results among male graduates of Fresno State College who had graduated 15 years previously. He found significant differences in salary between students defined as high in terms of extra-curricular participation and students who ranked lowest in participation. Graduates ranking high in co-curricular participation reported an average salary of $\$ 6,060$ per year, compared with an average salary of $\$ 4,393$ for people who had described themselves as uninvolved. Christenson (1969) also reported higher income as one of the long-term personal gains of students who participated in student government, as did Downey, Bosco, and Silver (1984) and Roskens (1958).

The research into the relationship between co-curricular involvement and salary level has resulted in mixed conclusions, with a few studies showing significant positive differences (Walters and Bray, 1963; Hunt, 1963), one indicating a trivial relationship (Kocher and Pascarella, 1988), and one reporting a negative correlation between involvement and salary (Havemann and West, 1952). There was little argument, 
however, that a college degree has a tremendous impact on earnings (Pascarella and Terenzini, 1991).

\section{$\underline{\text { Job Satisfaction }}$}

An additional variable found infrequently in the literature but shown to be related in several cases to student involvement is job satisfaction. Roskens, as early as 1958 , discovered that students who participated in college activities reported an increased level of job satisfaction as well as higher income, though he admitted that such conclusions were neither abundant nor entirely consistent. Downey, Bosco, and Silver (1984) also discovered a significant difference in the perceptions of job satisfaction among student leaders who were involved in student government, while Pascarella and Terenzini (1991) found that college graduates in general reported only modestly more employment satisfaction than people who had never attended college.

Pascarella and Terenzini (1991) reported an overall influence, albeit modest, on college attendance and the resulting intrinsic and extrinsic job satisfaction. Much of the theory behind the measurement of intrinsic and extrinsic job satisfaction was founded in Herzberg's Two Factor Theory (Herzberg, 1966). Mohrman, Cooke, Mohrman, Duncan, and Zaltman (1977), developed a tool to measure job satisfaction based upon Herzberg's theory. According to Mohrman, et. al. (1977), job satisfaction was a cumulative measure of intrinsic and extrinsic motivators. Intrinsic motivators were reported as personal rewards such as self-esteem, achievement, personal development, accomplishment, and fulfillment of expectations. Extrinsic motivators were defined as degree of respect and 
fair treatment, the feeling of being informed, the amount of supervision received, and the opportunity for participation in the decision-making process.

Pascarella and Terenzini (1991) explained the varied results of college completion and job satisfaction as related to extrinsic and intrinsic rewards. The researchers explained that, while college completion would tend to result in individuals being placed in positions with high levels of intrinsic and extrinsic rewards, those same graduates, as a result of their education, would be more critical of the rewards received and the opportunities available. Evidence in support of such a determination was found by Campbell (1981) and Gordon and Arvey (1975). Both researchers discovered that groups with the lowest level of educational attainment were more satisfied and less critical of employment situations.

\section{Summary}

From the review of the literature, the independent and dependent variables for this study became apparent. There had been a tremendous amount of investigation completed on how a college experience changes students. An abundance of that material dealt with the involvement of students in co-curricular activities. A synopsis of the development of leadership theory was provided, along with additional material on the history of co-curricular activities. Subsequentl research was compared on college student development and the evolution of student development theory.

Once the determination was made concerning the merits of student development theory and that involvement in co-curricular activities was a fundamental part of student development, it became necessary to ascertain measurable post-graduate outcomes 
resulting from such participation. From the literature, the most prevalent indicators for positive outcomes were the continued involvement of graduates in community and professional organizations, the holding of leadership positions within those organizations, salary, and self-perceived intrinsic, extrinsic, and overall job satisfaction. Based on that body of knowledge, the dependent variables for this study were chosen. 


\section{Chapter Three}

\section{Methods}

This study examined the statistical relationship between involvement in collegiate co-curricular activities and post-graduate social/civic involvement, professional involvement, leadership positions held, and salary (as measured by the West Virginia College and Community Involvement Survey). This study also examined the statistical relationship between the degree of involvement in collegiate co-curricular activities and perceived job satisfaction (as measured by the Mohrman-Cooke-Mohrman Job

Satisfaction Scale). This inquiry was based on the work of predominant researchers in the field, which was established in the previous chapters. Chapter Three will describe the research design that was used for the study, the population and sample, instrumentation, methods, and an overview of the data analysis procedures that were employed.

\section{Design}

This inquiry, as defined by Gay (1996), was considered to be a causalcomparative study. Data collection and the establishment of involved and uninvolved respondents resulted from survey responses gathered from a sample population. Once the data were collected, involved and uninvolved groups were categorized and then compared in terms of the dependent variables relative to the independent variable. Levels of collegiate involvement were compared with regard to post-graduate social/civic involvement, professional involvement, leadership positions held, salary, and self-perceived job satisfaction. 


\section{Population and Sample}

The population considered for this study was 1990 graduates of four-year state supported colleges in West Virginia (Bluefield State College, Concord College, Fairmont State College, Glenville State College, Shepherd College, West Liberty State College, and West Virginia State College). Ten years was determined by earlier researchers to be an adequate amount of time for a college graduate to become an established member of a community (Burton, 1974; Florestano, 1970; Kraft, 1951; Rokens, 1958; and Sommers, 1991). A list of the names and addresses of all 1990 baccalaureate graduates from these institutions was requested from each institutional registrar. The number of baccalaureate graduates from the aforementioned institutions in 1990 was 2,358 (N=2,358). Based upon the recommendation of Randolph (1974), an appropriate sampling size for a population of 2,358 is two percent or 47 . However, with the design and population for this study, a sample of $400(n=400)$, or $17 \%$ of the population was sampled. The sample population was designated by numbering each address label in the population and selecting the sample through the use of random number tables.

\section{$\underline{\text { Instrumentation }}$}

This study utilized two survey instruments to gather data. Demographic characteristics, collegiate involvement and leadership, and subsequent social/civic and professional involvement, leadership positions, and salary were measured with the West Virginia College and Community Involvement Survey (Appendix A). Self-perceived 
post-graduate job satisfaction was measured by the Mohrman-Cooke-Mohrman Job Satisfaction Scale (Appendix B).

The $W V C C I S$ was designed to be self-administered and was constructed to obtain three sets of information from the respondent. The first set of questions concerned demographic data, including age, sex, ethnicity, undergraduate college attended, degree received, and current annual income. The next set of questions pertained to the involvement of the respondent and leadership positions held while enrolled in college; particularly with regard to social, special interest, Greek, honors, service, and student government positions. A final section sought information regarding current involvement and leadership positions in social, civic, service, religious, fraternal, recreational, military, and professional organizations. Similar categories of activities to gather data were previously established by Burton (1974) and Florestano (1970).

Demographic and background information were noted for each response. Scores for undergraduate co-curricular involvement and subsequent community and professional involvement were obtained by assigning one point for each indicated activity and two points for elected or appointed leadership position held in each activity. Similar point systems had been developed by other researchers in order to measure levels of involvement by college students (Burton, 1974; Chapin, 1929; Gambrill, 1939).

The $M C M J S S$ was also designed to be self-administered, had proven effective in the measurement of self-perceived job satisfaction, and had been utilized in several other studies (Bare-Oldham, 1999; Crist, 1999; Hardman, 1996; Mathis, 1999; McKee, 1991; and Sirk, 1999). It was comprised of eight questions. The first four questions 
assessed intrinsic job satisfaction and the second four questions pertained to the assessment of extrinsic job satisfaction (Duncan, Mohrman, S., Mohrman, A., Cooke, and Zaltman, 1977). According to Herzberg (1966), overall job satisfaction was based on factors resulting from both intrinsic and extrinsic conditions. The MCMJSS is based on that theory (Duncan, et. al., 1977).

A limitation of a survey or a questionnaire is the ability to measure what the instrument intends to measure and whether the results remain the same in similar conditions. Because the WVCCIS was developed by this researcher and not based on an existing instrument, there is no comparison to determine validity. A panel of experts reviewed the $W V C C I S$ to establish content validity and determine approximate time needed for completion.

Using education professionals as respondents, reliability coefficients were established for the MCMJSS (Duncan, et. al., 1977). The reliability for the intrinsic scale ranged from .81 to .87 , and the reliability for the extrinsic scale ranged from .77 to .82 . Another study by Mohrman (1978) reported Chronbach alpha coefficients of .86 for intrinsic job satisfaction and .71 for extrinsic job satisfaction.

\section{$\underline{\text { Methods }}$}

This study was designed to determine if a significant statistical relationship existed between the level of student involvement in college and subsequent social/civic involvement, involvement in professional organizations, leadership positions held, salary, and job satisfaction during the ten-year period after graduation. Involved and 
uninvolved populations were then correlated based upon responses regarding answers provided on the survey and the MCMJSS.

The study utilized self-reported questionnaire survey procedures (Kerlinger and Lee, 2000) to gather the appropriate data. Each graduate in the sample population $(n=400)$ was mailed a packet of materials compiled by the researcher. The packet included a cover letter from the researcher (Appendix C) explaining the study, a copy of the $W V C C I S$, a copy of the MCMJSS, and an addressed and stamped reply envelope. The cover letter explained that participation in the study was voluntary, that anonymity was assured for participating subjects, and that the research project was reviewed and approved by the Human Subjects Review Board of West Virginia University.

Survey recipients were asked to complete the survey instruments and return them to the researcher within two weeks. A follow-up letter (Appendix D) and another set of instruments was sent three weeks after the initial mailing in an effort to achieve a higher return rate. A return rate of 50 percent plus one was sought prior to analysis of the data, as recommended by Kerlinger and Lee (2000).

\section{Data Analysis}

Upon receiving completed survey instruments, a numerical analysis was completed to determine levels of collegiate and post-graduate involvement. This was determined by the number of activities in which the respondent participated and the number of leadership positions held by the respondent while an undergraduate in college. When measuring the level of collegiate involvement, one point was given for each co-curricular activity in which the respondent participated. Respondents were then 
given two points for each elected or appointed leadership position held while participating in co-curricular activities. Respondents reporting collegiate involvement were classified as "involved." Respondents reporting no involvement were classified as "uninvolved."

The same point system was also be used to ascertain the level of post-graduation activity and involvement with one point given for each social/civic and professional organization affiliation and two points assigned for each appointed or elected leadership position held. Average salary ranges were also ascertained and perceived job satisfaction was measured by the MCMJSS, with total scores for intrinsic, extrinsic, and overall job satisfaction determined.

Spearman's rho and Kendall's tau_b Non-Parametric Statistical Correlations was used to determine if there was a significant statistical correlation between the level of collegiate involvement and subsequent characteristics. An alpha level of 0.05 was used as the level of significance for this study. Post hoc analyses were conducted as appropriate.

\section{Summary}

The procedures described in this chapter were designed to determine if involvement in co-curricular activities while in college had a statistically significant relationship with subsequent social/civic and professional involvement, salary (as measured by the $W V C C I S$ ), and self-perceived job satisfaction (as measured by the MCMJSS). A randomly selected sample of 1990 graduates from state-supported four-

year colleges in West Virginia was surveyed. Appropriate statistical tests at a 0.05 alpha 
level were performed and analyzed to answer the research questions. The following chapter presents the results of the data analysis. 


\section{Chapter Four}

\section{Presentation and Analysis of the Data}

\section{$\underline{\text { Introduction }}$}

This study examined the statistical relationship between collegiate involvement in co-curricular activities and subsequent post-graduate involvement in social organizations, civic organizations, and professional organizations, post-graduate salary, and post-graduate intrinsic job satisfaction, extrinsic job satisfaction, and overall job satisfaction. The sample population used for the study was 400 students $(n=400)$ selected at random from among the 2,358 $(\mathrm{N}=2,358) 1990$ graduates from the seven State-supported colleges in West Virginia (Bluefield State College, Concord College, Fairmont State College, Glenville State College, Shepherd College, West Liberty State College, and West Virginia State College). The West Virginia College and Community Involvement Survey (Appendix A) and the Mohrman-Cooke-Mohrman Job Satisfaction Scale (Appendix B) were the survey tools employed to gather the data.

Of the 400 surveys sent to the sample, 128 were returned as undeliverable. These surveys were not counted toward the return rate of the study, as allowed under research protocol described by Dillman (1978). According to Dillman, an acceptable return rate was the number of responses properly returned divided by the number in the total sample minus the sum of those non-eligible or unreachable. That number, when divided by 100 , provides the return rate. Of the remaining 272 surveys, 142 , or $52.2 \%$ were returned.

The results of this study are presented in the remainder of this chapter. Descriptive data gathered from the completed surveys are provided, followed by an 
outline regarding the scoring of the instrument. A statistical analysis of the data, a presentation of the major findings of the study, a presentation of ancillary findings of the study, and finally, a summary of the results is provided.

\section{Descriptive Data}

Using the West Virginia College and Community Involvement Survey, information concerning the respondents' age, sex, ethnicity, undergraduate institution, and degree received was collected. The age of the respondents ranged from 30 to 67 years, and the average age was 38 . Forty-six (32.4\%) were male and $95(66.9 \%)$ were female, 137 (96.5\%) were White, two (1.4\%) were Black, and one (0.7\%) reported ethnicity as "other."

The graduating institution was reported by all respondents. Six were from Bluefield State College, 19 from Concord College, 34 from Fairmont State College, 20 from Glenville State College, 34 from Shepherd College, 14 from West Liberty State College, and 15 from West Virginia State College. Four respondents did not report undergraduate major. Of the remaining 138, undergraduate majors were reported as follows: Behavioral Science (6), Psychology (7), Applied Science (1), Math (2), Biology (4), Regents Bachelor of Arts (15), Humanities (1), Education (26), Business (33), Engineering (3), Applied Health (1), Management (3), Sociology (1), History (2), Nursing (4), Fine Arts (2), Communications (5), Information Systems (1), Hotel/Restaurant Management (5), Accounting (5), Dental Hygiene (2), Travel (1), Geography (1), Computer Science (2), Recreation (1), Social Work (2), and Criminal Justice (2). 


\section{Scoring of the Instrument}

Data for this study were collected using the West Virginia College and Community Involvement Survey and the Mohrman-Cooke-Mohrman Job Satisfaction Scale. After the demographic information was collected, respondents were asked to list co-curricular activities participated in while working on an undergraduate degree. These activities were classified as Honor Societies/Groups, Service Organizations, Student Government/Activities, Special Interest Groups, and Sororities/Fraternities, which were the categories predominantly identified in the literature. Respondents were assigned one point for each organization listed in order to calculate an involvement score.

Respondents were also given two points for each leadership position listed within each activity. Respondents were categorized as either "involved" (listing one or more collegiate co-curricular activities) or "uninvolved" (respondents listing no involvement in collegiate co-curricular activities).

The sample population was also asked to respond in a similar manner to activities in which they had been involved since completing an undergraduate degree. These activities were categorized as Social/Interest Groups, Civic Organizations, Service Groups, Religious Organizations, Fraternal Organizations, Recreational Groups, Military Organizations, and Professional Organizations, which were the categories predominantly identified in the literature. Utilizing a scoring system similar to the first section on collegiate involvement, one point was assigned for each activity listed and two points were assigned for each leadership position within the listed organizations. 
The final portion of the instrument was the Mohrman-Cooke-Mohrman Job Satisfaction Scale. Respondents were presented with eight statements; four pertaining to intrinsic satisfaction with employment and four pertaining to extrinsic satisfaction. A six point scale was given after each statement and respondents were asked to rate their level of agreement with each statement on that scale (1=Lowest, $6=$ Highest). Sums of those responses provided total scores for intrinsic, extrinsic, and overall job satisfaction.

\section{Statistical Analysis of the Data}

The data for this study were analyzed using SPSS Software, Version 10.0. Nonparametric statistical correlation tests, Spearman's rho and Kendall's tau_b, were employed to determine if there was a statistically significant correlation between variables in the study. Both tools were appropriate as they measure the correlation between two sets of data when one variable is ordinal and the other is either ordinal, interval, or ratio; however, Kendall's tau_b is considered to be a more conservative statistical tool (Gay, 1996; Furlong, Lovelace, and Lovelace, 2000). A two-tailed alpha level of 0.05 was set as the criterion for determining significance, as the correlations could be either positive or negative. Analyses were conducted comparing the correlation between the categories of college involvement (independent variable and ordinal) and community involvement, professional involvement, leadership involvement, salary, and job satisfaction (dependent variables and ordinal or ratio, depending on the variable). Results were expressed in correlation coefficients ranging from -1.00 to +1.00 . Correlations between 0 to 0.29 were considered low. Correlations between 0.30 to 0.69 were considered moderate. Finally, correlations between 0.70 and 1.0 were considered to 
be strong correlations (Furlong, Lovelace, and Lovelace, 2000). Correlations can be either positive (with variables moving in the same direction) or negative (with variables moving in opposite directions).

\section{Major Findings}

The major findings for the study are presented in this section. The results for each question follow.

Question 1. What is the correlation, if any, between college co-curricular involvement and subsequent involvement in social, civic, service, religious, fraternal, recreational and/or military organizations?

A Spearman's rho and Kendall's tau_b was calculated to determine if there was a statistically significant correlation between college co-curricular involvement and subsequent involvement in community organizations. As presented in Table 1, a statistically significant low positive correlation was found by both tests to exist between collegiate co-curricular involvement and post-graduate community involvement in social, civic, service, religious, fraternal, recreational, and military organizations. This correlation would indicate that students categorized as involved in collegiate cocurricular activities scored higher in post-graduate involvement activities, or students involved in co-curricular activities were also involved in community activities after graduation. 
Table 1

$\underline{\text { Correlation Coefficients Between Collegiate Involvement and Community }}$ $\underline{\text { Involvement }}$

\begin{tabular}{lccc}
\hline Statistical Test & $\mathrm{N}$ & Correlation Coefficient & Significance \\
\hline Spearman's rho & 110 & $.268^{* *}$ & .005 \\
Kendall's tau_b & 110 & $.235^{* *}$ & .005 \\
\hline$* \mathfrak{p}<.01$, two-tailed. & & &
\end{tabular}

Question 2. What is the correlation, if any, between college co-curricular involvement and subsequent involvement in professional organizations?

A Spearman's rho and Kendall's tau_b was calculated to determine if there was a statistically significant correlation between college co-curricular involvement and subsequent involvement in professional organizations. As presented in Table 2, there was not a statistically significant correlation found by either test between collegiate cocurricular involvement and subsequent involvement in professional organizations. This finding would signify that respondents reporting involvement in co-curricular activities while in college were not any more or less likely to report involvement in professional organizations in the years following graduation. 
Table 2

$\underline{\text { Correlation Coefficients Between Collegiate Involvement and Post-Graduation }}$ $\underline{\text { Professional Involvement }}$

\begin{tabular}{lccc}
\hline Statistical Test & $\mathrm{N}$ & Correlation Coefficient & Significance \\
\hline Spearman's rho & 58 & .118 & .377 \\
Kendall's tau_b & 58 & .109 & .373 \\
\hline
\end{tabular}

Question 3. What is the correlation, if any, between the college co-curricular involvement and leadership positions held in community and professional organizations?

A Spearman's rho and Kendall's tau_b was calculated to determine if there was a statistically significant correlation between college co-curricular involvement and subsequent leadership positions held in both community and/or professional organizations. As presented in Table 3, a statistically significant low positive correlation was found by both tests to exist between collegiate co-curricular involvement and subsequent leadership positions held in community and professional organizations. This finding would indicate that respondents reporting involvement in collegiate co-curricular activities also reported involvement in leadership positions within community and professional organizations. 
Table 3

$\underline{\text { Correlation Coefficients Between Collegiate Involvement and Post-Graduation }}$ $\underline{\text { Community and Professional Leadership Positions }}$

\begin{tabular}{llcc}
\hline Statistical Test & $\mathrm{N}$ & Correlation Coefficient & Significance \\
\hline Spearman's rho & 142 & $.212^{*}$ & .011 \\
Kendall's tau_b & 142 & $.196^{*}$ & .012 \\
\hline$* \mathrm{p}<.05$, two-tailed. & &
\end{tabular}

Question 4. What is the correlation, if any, between college co-curricular involvement and current salary?

A Spearman's rho and Kendall's tau_b was calculated to determine if there was a statistically significant correlation between college co-curricular involvement and current salary as reported by the respondents. As presented in Table 4, no statistically significant correlation was found by either test to exist between collegiate co-curricular involvement and subsequent salary. This result signifies that respondents who reported involvement in collegiate co-curricular activities reported no significant difference in post-graduate salary that those respondents who reported no co-curricular involvement.

\section{Table 4}

$\underline{\text { Correlation Coefficients Between Collegiate Involvement and Reported Current }}$ $\underline{\text { Salary }}$

\begin{tabular}{lccc}
\hline Statistical Test & $\mathrm{N}$ & Correlation Coefficient & Significance \\
\hline Spearman's rho & 140 & .021 & .803 \\
Kendall's tau_b & 140 & .019 & .802 \\
\hline
\end{tabular}


Question 5. What is the correlation, if any, between college co-curricular involvement and intrinsic, extrinsic, and overall satisfaction with current employment?

A Spearman's rho and Kendall's tau_b was calculated to determine if there was a statistically significant correlation between college co-curricular involvement and postgraduate intrinsic, extrinsic, and overall job satisfaction. As presented in Table 5, a statistically significant correlation between collegiate co-curricular involvement and subsequent intrinsic, extrinsic, and overall job satisfaction was not indicated. This finding disclosed that respondents who reported co-curricular involvement in college reported no significant increase or decrease in levels of job satisfaction over those respondents who reported no involvement.

\section{Table 5}

Correlation Coefficients Between Collegiate Involvement and Reported Intrinsic, Extrinsic, and Overall Job Satisfaction

\begin{tabular}{rccc}
\hline Statistical Test & $\mathrm{N}$ & Correlation Coefficient & Significance \\
\hline Spearman's rho & & .117 & \\
Intrinsic & 142 & -.057 & .164 \\
Extrinsic & 142 & .012 & .498 \\
Overall & 142 & & .890 \\
Kendall's tau_b & & .099 & .163 \\
Intrinsic & 142 & -.048 & .496 \\
Extrinsic & 142 & .010 & .889 \\
Overall & 142 & & \\
\hline
\end{tabular}




\section{Ancillary Findings}

In addition to the five independent variables included in the major findings, there were several subsequent findings which were of interest. These additional analyses follow and were tested using both Spearman's rho and Kendall's tau_b statistical tools.

Significant moderately positive correlations were found between post-collegiate community involvement and involvement in religious, recreational, and professional organizations. That finding indicated that respondents who reported being involved in post-graduate activities were involved primarily in religious, recreational and professional organizations. This relationship is shown in Table 6.

Table 6

$\underline{\text { Correlation Coefficients Between Post-Graduation Community Involvement and }}$ Involvement in Religious, Recreational, and Professional Organizations

\begin{tabular}{llll}
\hline Statistical Test & $\mathrm{N}$ & Correlation Coefficient & Significance \\
\hline Spearman's rho & & & \\
Religious Involvement & 49 & $.398^{* *}$ & .005 \\
Recreational Involvement & 29 & $.529 * *$ & .003 \\
Professional Involvement & 58 & $.423 * *$ & .001 \\
Kendall's tau_b & & & .006 \\
Religious Involvement & 49 & $.339 * *$ & .005 \\
Recreational Involvement & 29 & $.455^{* *}$ & .001 \\
Professional Involvement & 58 & $.358^{* *}$ &
\end{tabular}


A significant low positive correlation was found between post-collegiate community involvement and the holding of leadership positions within those organizations. That finding would indicate that those respondents who were involved in post-graduate community and professional activities were also likely to hold positions of leadership within those organizations. This relationship is shown in Table 7.

Table 7

$\underline{\text { Correlation Coefficients Between Post-Graduate Community Involvement and the }}$ $\underline{\text { Holding of Leadership Positions within Organizations }}$

\begin{tabular}{llcc}
\hline Statistical Test & $\mathrm{N}$ & Correlation Coefficient & Significance \\
\hline Spearman's rho & 142 & $.212^{*}$ & .011 \\
Kendall's tau_b & 142 & $.196^{*}$ & .012 \\
\hline
\end{tabular}

$* \underline{p}<.05$, two-tailed.

A significant low positive correlation was found between post-graduate community involvement and post-graduate intrinsic job satisfaction. Similar results were not found when comparing post-graduate extrinsic and overall job satisfaction. This finding would indicate that respondents reporting higher levels of post-graduate involvement in community and professional organizations also reported higher levels of post-graduate intrinsic satisfaction with current employment. This relationship is shown in Table 8. 
Table 8

Correlation Coefficients Between Intrinsic, Extrinsic, and Overall Job Satisfaction and Post-Graduation Community Involvement

\begin{tabular}{cccc}
\hline Statistical Test & $\mathrm{N}$ & Correlation Coefficient & Significance \\
\hline Spearman's rho & & & \\
Intrinsic & 110 & $.227^{*}$ & .017 \\
Extrinsic & 110 & .105 & .275 \\
Overall & 110 & .181 & .059 \\
Kendall's tau_b & 110 & & .014 \\
Intrinsic & 110 & $.176^{*}$ & .264 \\
Extrinsic & 110 & .079 & .057 \\
Overall & & .134 &
\end{tabular}

A significant low positive correlation was found between intrinsic job satisfaction and post-graduate leadership involvement. Similar results were not found when comparing extrinsic and overall job satisfaction. This finding would indicate that respondents reporting higher levels of post-graduate leadership involvement also reported higher levels of post-graduate intrinsic job satisfaction. This relationship is shown in Table 9. 
Table 9

Correlation Coefficients Between Intrinsic, Extrinsic, and Overall Job Satisfaction $\underline{\text { and Post-Graduate Leadership Involvement }}$

\begin{tabular}{cccc}
\hline Statistical Test & $\mathrm{N}$ & Correlation Coefficient & Significance \\
\hline Spearman's rho & & & \\
Intrinsic & 142 & $.196^{*}$ & .019 \\
Extrinsic & 142 & .033 & .697 \\
Overall & 142 & .082 & .331 \\
Kendall's tau_b & 142 & & .020 \\
Intrinsic & 142 & $.153 *$ & .666 \\
Extrinsic & 142 & .028 & .349 \\
Overall & & .061 & \\
\hline $\mathrm{p}<.05$, two-tailed. & & &
\end{tabular}

A significant low to moderate positive correlation was found between reported salary and intrinsic, extrinsic, and overall job satisfaction. This finding would indicate that those respondents reporting higher salary levels also reported higher intrinsic, extrinsic, and overall job satisfaction in current employment. This relationship is shown in Table 10. 
Table 10

Correlation Coefficients Between Salary and Intrinsic, Extrinsic, and Overall Job $\underline{\text { Satisfaction }}$

\begin{tabular}{cccc}
\hline Statistical Test & $\mathrm{N}$ & Correlation Coefficient & Significance \\
\hline Spearman's rho & & & \\
Intrinsic & 140 & $.358^{* *}$ & .000 \\
Extrinsic & 140 & $.319^{* *}$ & .000 \\
Overall & 140 & $.325^{* *}$ & .000 \\
Kendall's tau_b & & & .000 \\
Intrinsic & 140 & $.269^{* *}$ & .000 \\
Extrinsic & 140 & $.241^{* *}$ & .000 \\
Overall & 140 & $.244^{* *}$ & \\
\hline
\end{tabular}

** $\mathrm{p}<.001$, two-tailed.

A significant low/moderate negative correlation was found between reported salary and sex. This finding would indicate that men reported making higher salaries than women. This relationship is shown in Table 11.

Table 11

Correlation Coefficients Between Reported Salary and Sex

\begin{tabular}{lccc}
\hline Statistical Test & $\mathrm{N}$ & Correlation Coefficient & Significance \\
\hline Spearman's rho & 139 & $-.343^{* *}$ & .000 \\
Kendall's tau_b & 139 & $-.299^{* *}$ & .000 \\
\hline
\end{tabular}

$* * \mathrm{p}<.001$, two-tailed. 
Data were also broken down by institution (Bluefield State College, Concord College, Fairmont State College, Glenville State College, Shepherd College, West Liberty State College, and West Virginia State College). No significant correlations were found between institution attended and either level of collegiate involvement, level of post-graduation involvement, or overall job satisfaction.

\section{Summary}

The purpose of this study was to determine if there were statistically significant correlations between involvement in co-curricular activities in college and post-graduate involvement in community and professional organizations, the holding of leadership positions in community and professional organizations, salary, and self-perceived job satisfaction. These independent variables were chosen due to their prominence in the literature of the field.

Of the 272 returnable surveys sent to 1990 graduates of four-year state colleges in West Virginia, 142, or 52.2 percent, were completed and returned. Demographic data, level of collegiate co-curricular involvement, and post-graduation community involvement were compiled from the WVCCIS (Appendix A). Intrinsic, extrinsic, and overall job satisfaction were compiled using the MCMJSS (Appendix B). The WVCCIS was designed by the researcher. Both instruments were reviewed by a panel of experts for readability and content validity.

In order to determine significant correlations between variables Spearman's rho and Kendall's tau_b was determined to be the appropriate statistical tests. The research data were analyzed using SPSS, Version 10. 
Significant statistical correlations were found to exist between college involvement and community involvement, and college involvement and the holding of leadership positions in community and professional organizations. Significant statistical correlations were not found to exist between college involvement and professional involvement, college involvement and current salary, and college involvement and intrinsic, extrinsic, and overall job satisfaction. Ancillary findings included the discovery of significant statistical correlations between post-graduation community involvement and involvement in religious, recreational, and professional organizations, post-graduation community involvement and the holding of leadership positions in those organizations, post-graduation community involvement and intrinsic job satisfaction, post-graduation leadership positions and intrinsic job satisfaction, salary and intrinsic, extrinsic, and overall job satisfaction, and salary and sex. No significant correlations were discovered among individual institutions with regard to co-curricular involvement, post-graduate community and professional involvement, community leadership, and intrinsic, extrinsic and overall job satisfaction. 


\section{Chapter Five}

\section{Summary, Conclusions, and Recommendations for Further Study}

This chapter provides summaries of the purpose of the study, procedures incorporated into the study, demographics of the sample population, and findings of the study. Conclusions, implications, and recommendations for further research constitute the remainder of the chapter.

\section{Summary of Purpose}

The purpose of this study was to determine if there was a significant statistical correlation between collegiate co-curricular involvement and post-graduate involvement in community and professional organizations, leadership positions in those organizations, current salary, and intrinsic, extrinsic, and overall job satisfaction. From the literature and the variables encompassed within, the following research questions were developed:

1. What is the correlation, if any, between co-curricular college involvement and post-graduate involvement in social, civic, service, religious, fraternal, recreational and/or military organizations?

2. What is the correlation, if any, between college co-curricular involvement and post-graduate involvement in professional organizations?

3. What is the correlation, if any, between the college co-curricular involvement and leadership positions held in community and professional organizations? 
4. What is the correlation, if any, between college co-curricular involvement and current salary?

5. What is the correlation, if any, between college co-curricular involvement and intrinsic, extrinsic, and overall satisfaction with current employment?

\section{$\underline{\text { Summary of the Procedures }}$}

A causal-comparative study research design was used to determine the correlation between the independent variable (college co-curricular involvement) and dependent variables (post-graduate involvement in community and professional organizations, leadership positions held in community and professional organizations, salary, and intrinsic, extrinsic, and overall job satisfaction) (Gay, 1996). The population under consideration consisted of graduates from four-year state-supported colleges in 1990 (Bluefield State College, Concord College, Fairmont State College, Glenville State College, Shepherd College, West Liberty State College, and West Virginia State College $)(\mathrm{N}=2,358)$. A random sample consisting of $17 \%$ of the population $(\mathrm{n}=400)$ was selected from the population. Each person in the sample population was mailed a packet that included a cover letter (Appendix C), a copy of the West Virginia College and Community Involvement Survey (WVCCIS) (Appendix A), a copy of the MohrmanCooke-Mohrman Job Satisfaction Survey (MCMJSS) (Appendix B), and a selfaddressed-stamped envelope. Three weeks after the initial mailing a follow-up mailing containing the same instruments and a reminder was sent with another request to complete and return the survey instruments (Appendix D). Of the 400 survey sent, 128 were returned as undeliverable. Of the remaining 272 surveys, 142 were returned 
completed. This provided for a return rate of $52.2 \%$. The response rate exceeds the $50 \%$ plus one recommended for this type of study (Kerlinger and Lee, 2000).

The WVCCIS consisted of three components. The first solicited demographic information including sex, ethnicity, age, degree completed, college attended, and salary. The second asked for a listing of collegiate co-curricular organizations (honor societies, service organizations, student government/activities groups, special interest groups, and sororities and fraternities) in which the respondent was a member and leadership positions the respondent held in those organizations. The third section requested a listing of memberships in organizations since the student graduated from college (social/interest groups, civic organizations, service groups, religious organizations, fraternal organizations, recreational groups, military organizations, and professional organizations), and any leadership positions held within the organizations listed.

The survey population was also asked to complete the MCMJSS. This instrument lists four statements relative to intrinsic job satisfaction and four statements relative to extrinsic job satisfaction. Respondents were asked to rate their level of agreement with each statement. Averaging intrinsic and extrinsic scores provided a score for overall job satisfaction.

\section{$\underline{\text { Summary of Descriptive Data }}$}

Responses to the $W V C C I S$ and the MCMJSS provided information about the respondents' sex, age, ethnicity, college attended, degree obtained, and salary. Of the 142 respondents, $46(32.4 \%)$ were male and $95(66.9 \%)$ were female, $137(96.5 \%)$ were White, two (1.4\%) were Black, and one (0.7\%) reported ethnicity as "other." 
The graduating institution was reported by all respondents. Six were from Bluefield State College, 19 from Concord College, 34 from Fairmont State College, 20 from Glenville State College, 34 from Shepherd College, 14 from West Liberty State College, and 15 from West Virginia State College. Four respondents did not report undergraduate major. Of the remaining 138, undergraduate majors were reported as follows: Behavioral Science (6), Psychology (7), Applied Science (1), Math (2), Biology (4), Regents Bachelor of Arts (15), Humanities (1), Education (26), Business (33), Engineering (3), Applied Health (1), Management (3), Sociology (1), History (2), Nursing (4), Fine Arts (2), Communications (5), Information Systems (1), Hotel/Restaurant Management (5), Accounting (5), Dental Hygiene (2), Travel (1), Geography (1), Computer Science (2), Recreation (1), Social Work (2), and Criminal Justice (2).

Salary was reported by all but two of the respondents. Fourteen reported an annual income of less than $\$ 10,000,13$ reported an annual income of $\$ 10,000$ to $\$ 20,000,28$ reported an annual income of $\$ 20,001$ to $\$ 30,000,28$ reported an annual income of $\$ 30,001$ to $\$ 40,000,12$ reported an annual income of $\$ 40,001$ to $\$ 50,000,17$ reported an annual income of $\$ 50,001$ to $\$ 60,000,8$ reported an annual income of $\$ 60,001$ to $\$ 70,000$, and 20 reported an annual income of over $\$ 70,000$.

\section{Summary of Findings}

Question 1 - What is the correlation, if any, between co-curricular college involvement and post-graduate involvement in social, civic, service, religious, fraternal, recreational and/or military organizations? 
A statistically significant low positive correlation was found to exist between cocurricular college involvement and post-graduate involvement in social, civic, service, religious, fraternal, recreational and/or military organizations. This would indicate that respondents categorized as "involved" in collegiate co-curricular activities were more likely to indicate higher levels of post-graduate involvement in social, civic, service, religious, fraternal, recreational and/or military organizations.

Question 2 - What is the correlation, if any, between college co-curricular involvement and post-graduate involvement in professional organizations?

Respondents were asked to indicate any post-graduate professional organizations in which they were involved. There was no statistically significant relationship found to exist between collegiate co-curricular involvement and post-graduate involvement in organizations relating to one's chosen profession.

Question 3 - What is the correlation, if any, between the college co-curricular involvement and leadership positions held in community and professional organizations?

A statistically significant low positive correlation was found to exist between collegiate co-curricular involvement and post-graduate leadership positions held in community and professional organizations. This finding indicates that respondents who reported involvement in co-curricular activities in college also cited more leadership positions in community and professional organizations after graduation.

Question 4 - What is the correlation, if any, between college co-curricular involvement and current salary? 
The findings of the study did not indicate a significant relationship between the level of collegiate co-curricular involvement and post-graduate salary. The results were similar between respondents who reported co-curricular involvement and those who did not.

Question 5 - What is the correlation, if any, between college co-curricular involvement and intrinsic, extrinsic, and overall satisfaction with current employment?

The findings of the study did not indicate a significant relationship between collegiate co-curricular and either post-graduate intrinsic, extrinsic, or overall job satisfaction. The results were similar between respondents who reported co-curricular involvement and those who did not.

\section{$\underline{\text { Conclusions }}$}

The analysis of data indicated that the following conclusions could be made about the research questions designated in this study. The research questions are discussed in the order they were presented in Chapter One of this study.

Question 1 - What is the correlation, if any, between co-curricular college involvement and post-graduate involvement in social, civic, service, religious, fraternal, recreational and/or military organizations?

A statistically significant low positive correlation was found to exist between cocurricular college involvement and post-graduate involvement in social, civic, service, religious, fraternal, recreational and/or military organizations. This would indicate that respondents categorized as "involved" in collegiate co-curricular activities were more likely to indicate higher levels of post-graduate involvement in social, civic, service, religious, fraternal, recreational and/or military organizations after graduation. 
The results of this correlation were comparable with all of the major studies examined utilizing similar variables. Swenson's (1983) entire sample of 200 student leaders from three universities attributed later civic involvement to co-curricular involvement while in college. Burton (1974) reached a similar conclusion when studying graduates from the University of Missouri - Rolla in the 1960s. Bennett (1956), Holloway (1998), Sermersheim (1996), Kraft (1951), and Schultz and Garrett (1965) were all among researchers who concluded that there was a significant relationship between students who were involved in co-curricular activities while enrolled in college and graduates who were active in community and civic organizations.

Question 2 - What is the correlation, if any, between college co-curricular involvement and post-graduate involvement in professional organizations?

Respondents were asked to indicate any post-graduate professional organizations in which they were involved. There was not a statistically significant relationship found to exist between collegiate co-curricular involvement and post-graduate involvement in organizations relating to one's chosen profession.

The lack of a statistically significant relationship between co-curricular involvement and subsequent professional involvement was atypical when compared to the relevant research. Schultz and Garrett (1965), in a survey of over 4000 Phi Theta Kappa Alumni, found that $95 \%$ of the respondents became active in professional and business organizations subsequent to graduation. Florestano (1970), examining male student leaders from the University of Maryland in the 1950s, found that those leaders scored significantly higher in four of seven participation sub-scales on a leadership inventory, including one described as "professional and occupational." 
Question 3 - What is the correlation, if any, between the college co-curricular involvement and leadership positions held in community and professional organizations?

A statistically significant low positive correlation was found to exist between collegiate co-curricular involvement and post-graduate leadership positions held in community and professional organizations. This finding indicates that respondents who reported involvement in co-curricular activities in college also cited more leadership positions in community and professional organizations after graduation.

The statistical relationship ascertained in Question 3 was congruent with similar results from historical studies investigating the same question. Sommers (1991) found a high positive correlation between college co-curricular involvement and leadership positions held in community and professional organizations subsequent to graduation. Similar results were found from a population of male graduates from the University of Iowa (Roskens, 1958). LaBard (1999) discovered the same relationship existed among a population of community college students. All of the research reviewed for this study, along with the results of this research, indicate a strong relationship between student cocurricular involvement and subsequent leadership positions held in community and professional organizations.

Question 4 - What is the correlation, if any, between college co-curricular involvement and current salary?

The findings of the study did not indicate a significant statistical relationship between the level of collegiate co-curricular involvement and post-graduate salary. The results were similar between respondents who reported co-curricular involvement and those who did not. 
In the literature of the field, salary was a variable which was linked with varying results when compared to co-curricular student involvement, and most of the research comparing the two variables was somewhat dated. Bridgman (1930), in the earliest known recorded study, found that $48 \%$ of respondents at Bell Telephone reporting substantial college involvement also indicated a salary in the top one-third of the sample, while $28 \%$ of those reporting no college involvement placed at the same income level.

Havemann and West (1952) found contradictory results, however, when examining graduates from 1910 to 1940 . The results actually indicated a statistically significant negative correlation between co-curricular involvement and subsequent salary, though results were attributed to the negative perception of co-curricular involvement during that time, especially regarding the older graduates.

Jepson (1951), Roskens (1958), Christenson (1969), and Downy, Bosco, and Silver (1984) all reported significant increases in income for students active in cocurricular pursuits. Results from a study by Kocher abd Pascarella (1988) indicated that the relationship was trivial. While the prevailing results indicated that a relationship was statistically present, the results of this study did not indicate such a affiliation. Question 5 - What is the correlation, if any, between college co-curricular involvement and intrinsic, extrinsic, and overall satisfaction with current employment?

The findings of the study did not indicate a significant relationship between collegiate co-curricular and either post-graduate intrinsic, extrinsic, or overall job satisfaction. The results were similar between respondents who reported co-curricular involvement and those who did not. 
In the three studies examined earlier in this research, all concluded that students who reported a high level of co-curricular involvement in college also reported an increased level of satisfaction with employment. Roskens (1958), in addition to his findings related to salary, also reported that respondents indicated a higher level of job satisfaction. Downy, Bosco, and Silver reported similar results from students who were involved in student government. Pascarella and Terenzini (1991) reported only a modest increase in employment satisfaction between college graduates in general when compared to a population who had never attended college. The findings were attributed, however, to college graduates in general being more critical of employment situations.

\section{$\underline{\text { Implications }}$}

Earlier in this study, a great amount of discussion was lent to historical studies of college student involvement and the effect of that involvement on the characteristics of college graduates. It was also shown that this research would be different from the majority of earlier studies in that it was quantitative in nature, the sample population would contain both male and female respondents, and respondents from the same sample, both involved and uninvolved students, would be compared against each other in terms of the dependent variables. In the course of doing this, the findings of this study were mixed when compared to earlier research.

This study noted a significant positive correlation between involvement in collegiate co-curricular activities and post-graduate involvement in community organizations. The correlation indicated that students who were involved while in college were more likely to participate in these organizations after graduation. Similar 
findings were also discovered by Swenson (1983), Burton (1974), Holloway (1998), and Minihan (1957). This would indicate that participation in collegiate co-curricular activities does have an impact on later involvement in community organizations and that efforts should be made by institutions of higher education to encourage co-curricular participation and provide an arena conducive to the development of student organizations.

Although Shultz and Garrett (1965) discovered that 95\% of 4000 Phi Theta Kappa alumni were active in professional organizations, the results of this study did not bear the same conclusion. Respondents who were categorized as "involved" were statistically just as likely to belong to professional organizations relating to their employment as those who were categorized as "uninvolved."

College graduates who were involved in co-curricular activities and later held leadership positions in community and professional organizations were studied by Bennett (1956), Sommers (1991), and Roskens (1958). All three studies indicated that students who were involved in collegiate co-curricular activities were more likely to hold leadership positions in community and professional organizations after graduation. The results of this study concur with those findings. A significant statistical positive correlation was found between involvement at the college level and post-graduate leadership positions in community and professional organizations. Again, it is important for colleges and universities to realize where the seeds of such activity and involvement are sown and plan for such activity. 
The relationship between collegiate co-curricular involvement and post-graduate salary has been explored by several researchers. A positive correlation between cocurricular involvement and post-graduate salary was found by Swenson (1983), Bridgman (1930), Gambrill (1939), Jepson (1951), Christenson (1969), Roskens (1958), Walters and Bray (1963), Hunt (1963), and Downey, Bosco, and Silver (1984), meaning that college graduates who were involved in co-curricular activities reported earning higher salaries than those who were not involved. Only Havemann and West (1952) discovered a statistically significant negative correlation when examining these two variables, meaning that, in their studies, students who were involved in co-curricular activities actually reported earning less than those who were not involved. The results of this study found no significant correlation either way between the level of involvement in co-curricular activities and salary.

Increased job satisfaction as a result of collegiate co-curricular involvement was a hypothesis put forward by Swenson (1983), Sermersheim (1996), Roskens (1958), and Downey, Bosco, and Silver (1984). In results, however, found similar to that of salary, no significant correlation was found between collegiate co-curricular involvement and post-graduate intrinsic, extrinsic, and overall job satisfaction.

Ancillary findings provided several interesting conclusions that were supported elsewhere in the literature. While Burton (1974) found that involved students were more involved on charitable, recreational, and social organizations after graduation, this study resulted in a statistically significant positive correlation between post-graduate involvement and involvement in religious, recreational, and professional organizations. 
That would indicate that, of all college graduates who become involved later in organizations, some degree of that involvement would be in either religious, recreational, or professional organizations. This study similarly concluded that there was a statistically significant positive correlation between post-graduate community involvement and the holding of leadership positions within those organizations. That would demonstrate that respondents who were involved in community organizations after graduation were statistically more than likely to hold leadership positions within those organizations.

While no statistically significant relationship was found to exist between collegiate co-curricular involvement and intrinsic, extrinsic, or overall job satisfaction, a statistically significant correlation was discovered between post-graduate community involvement and intrinsic job satisfaction and post-graduate leadership in community organizations and intrinsic job satisfaction. This finding would indicate that respondents who were involved in and/or held leadership positions in community organizations found more intrinsic value in their employment. Sermersheim (1996) discovered that activities in college which begat intrinsic rewards would lead to similar participation and the seeking of intrinsic rewards after graduation. Therefore, it could be concluded that respondents in this study who are intrinsically motivated to join community organizations after graduation also see employment as a method of achieving intrinsic rewards.

Two findings in this study regarding salary were significant. First, the results indicated that there was a statistically significant positive correlation between salary and 
intrinsic, extrinsic, and overall job satisfaction. This would indicate, at least by the results of this research, that money does indeed buy happiness. Secondly, this study discovered a statistically significant moderately negative correlation between salary and sex, meaning that there was a salary gap between males and females. This phenomenon has been reported frequently in the literature.

Finally, there is relevance in the fact that there were no significant differences found between individual institutions concerning level of collegiate involvement, level of post-graduate involvement, extent of post-graduate leadership positions held in community organizations, and post-graduate intrinsic, extrinsic, and overall job satisfaction. The results would indicate that each institution, on an individual basis, is serving the needs of the student as well as or in a manner similar to the others. No individual institution was recognized as having data significantly different than the other.

In general, when compared to other quantitative studies in the field, the results of this West Virginia study were not what would have been expected. Significant relationships were not indicated in areas where the literature indicated that such a relationship would be anticipated. Furthermore, in areas where statistically significant relationships were indicated, the correlations were not as strong as those found in other studies.

Several rationalizations could be made that would indicate the reasons for these differences. First, recent quantitative research studies of a similar nature have been sporadic and the nature and focus of higher education and student development have 
changed since many of the previous studies were conducted. Second, as discussed earlier in this project, many of the studies examined investigated students who were preselected as leaders, conducted research on only one or two campuses, and measured only male respondents. It is entirely possible that these factors could account for many of the disparities between this body of research and previous findings. It would also be conceivable that the institutions studied in West Virginia could benefit from an internal analysis of the programs and services in student development to ascertain if there are campus-based explanations for the differences between anticipated and actual results.

There are enough significant results to indicate, however, that involvement in cocurricular activities while in college does have a relationship with post-graduate involvement and leadership. Overwhelmingly, the research indicates that this type of activity has a positive influence on the development of a student as a professional and as an individual, and that this type of involvement is one of the organizing factors of higher education.

Institutions of higher education, both in West Virginia and across the country, must take these facts into consideration when allocating resources for student affairs programs, determining the role and function of student affairs programs within the scope of the institution, deciding the type and quality of education to be bestowed upon graduates, and ascertaining the role of higher education in the civic community. The development of active citizens and student leaders has often been cited as an important mandate for colleges and universities (Bialek and Lloyd, 1998; Byer, 1998; National Association of Student Personnel Administrators, 1987; Newton, 1975; Smitter, 1998). 
Striffolino and Saunders (1989) encouraged student affairs professionals to take an active and aggressive role in the development of students, not only as scholars, but as citizens as well. If it is a basic assumption that human development is an organizing purpose for higher education (Chickering and Reisser, 1993), and if colleges and universities are charged with producing leaders (McIntyre, 1989), then the significance of providing opportunities for student involvement and leadership development is apparent.

The preceding authors exhort a philosophy that student development is an important role for higher education. Other research examined in this study establishes that involvement in co-curricular activities is an important means to that end, and that such involvement has a positive influence on the lives of graduates and leads to enhanced success and involvement in community activities and affairs. Benson (1993) summarized this requisite when he wrote that "It is unlikely that any society can thrive unless citizens are able and willing to sacrifice personal gain for the common good" ( $p$. 34). Blume and Schwartz (1992) explained that today's society needed change, which could only come about through the involvement and leadership of participants in higher education. Nolin, Chapman, and Chandler (1997) responded to one of the National Education Goals. The goal stated that students in American schools should learn to use their minds well, so that they may be prepared for responsible citizenship. This study adds to the existing body of literature corroborating that co-curricular involvement is beneficial to the student as well as the common good of the community. 
Gulick and Urwick (1937) reported on the major tasks of management: planning, organizing, staffing, directing, coordinating, reporting, and budgeting. With regard to student affairs professionals, this study will have implications in each of these areas. If research continues to show that student development and involvement has a statistically significant relationship on the involvement and leadership participation of students after they graduate, then higher education institutions must continue to plan for such development. Furthermore, such findings will encourage institutions of higher education to organize departments with appropriate staffing to reach such ends. These efforts must also be directed and coordinated as part of the role and function of the mission of student affairs. Such endeavors must also allocate appropriate budgeting to support such activities. The results of the activities are then reported as part of the function of the institution as a whole and assists the higher education institution in educating leaders for society.

G. Dungy (personal communication, December 20, 2001), in a survey of 389 higher education institutions sponsored by the National Association of Student Personnel Administrators, found that over $90 \%$ of student affairs divisions were responsible for the functions of student government, activities, and organizations. In recent years, the role and function of these divisions had expanded to include enrollment management, cooperative education, and several other services that had previously been housed in either academic or administrative services. As roles are added, the function of activities and organizations should not be overlooked in terms of importance to student learning and success. Dungy continued: 
While current areas of responsibility define the roles of student affairs professionals on individual campuses, it appears that in the future we can expect more variance in functions, not necessarily due to institutional type, but because of the demands of the market place regarding accountability and the demand for more value for the dollar.

Given the previous foresight, research determining the value of participation in cocurricular activities is critical as the "worth" of such involvement may not be apparent until some years after the student graduates and is not necessarily a high profile market function.

\section{Recommendations for Further Research}

An analysis of the findings of this study has identified the following recommendations for further study.

1. The results of this study were limited to four-year state-supported schools in West Virginia. Further research could be conducted to include other states, private institutions, community colleges, or any number of additional categorizations.

2. A significant body of literature exists concerning qualitative measures of perceived benefits of co-curricular involvement in college. Additional research could be conducted to add a qualitative section to this type of study. 
3. The same survey could be conducted among graduates from the same institutions in 1980 and compared to these results to determine if there are trends emerging over periods of time.

4. The same survey could be conducted among another group of institutions and the results compared to this study to determine of there are significant differences between groups of institutions (e.g., state to state, public to private, 4-year to 2year, etc.).

5. Additional analyses could be conducted using the data from this study to determine if there are significant differences between females and males in terms of level of involvement and leadership positions held. 


\section{Bibliography}

Altbach, P.G. (1974). Student policies in America. New York: McGraw-Hill.

American Council on Education. (1937). The student personnel point of view. Washington, DC: Author.

American College Personnel Association (1994). The student learning imperative: Implications for student affairs. Washington, DC: Author.

Association of College Unions - International. (1982). College unions: Fifty facts. Bloomington, IN: Author.

Astin, A.W. (1978). Four critical years. San Francisco: Jossey-Bass.

Astin, A.W. (1984). Student involvement: A developmental theory for higher education. Journal of College Student Personnel, 25(4), 297-308.

Astin, A.W. (1993). What matters in college: Four critical years revisited. San Francisco: Jossey-Bass.

Astin, A.W., Astin, H., Bloland, P., Cross, K.P., Hearst, J., Kuh, G., Marchese, T., Nuss, E., Pascarella, E., Pruitt, A., Rooney, M., and Schroeder, C. (1994). The student learning imperative: Implications for student affairs. Washington, DC: American College Personnel Association.

Auble, C.S., and Auble, D. (1953, December). Relation between high school and college participation in extra-curriculum activities. School Review, 61, 541-543.

Bare-Oldham, K.M. (1999). An examination of the perceived leadership styles of Kentucky public school principles as determinants of teacher job satisfaction. (Doctoral dissertation, West Virginia University, 1999). Dissertation Abstracts International, 61, 823 .

Barsi, L.M., Hand, B.E., and Kress, J.L. (1985). Training effective student leaders: Back to the basics. NASPA Journal, 22(4), 26-30.

Bass, B.M. (1981). Stogdill's handbook of leadership. New York: The Free Press.

Behling, O. and Rauch, C.F. (1985). A functional perspective on improving leadership effectiveness. Organizational Dynamics, 13(4), 51-61. 
Bennett, F.A. (1956). The relationship between participation in student activities in certain New York State high schools and later civic and social participation. (Doctoral dissertation, Cornell University, 1956). Dissertation Abstracts International, 16,1369.

Benson, P.L. (1993). The troubled journey: A portrait of 6th-12th grade youth. Minneapolis, MN: Search Institute.

Berman, W.F. (1978). Student activities and student development. NASPA Journal, $16(2), 52-54$.

Bialek, Steven C., and Groves-Lloyd, Ann. (1998). Post graduation impact of student leadership. Alexandria, VA: American College Personnel Association. (ERIC Document Reproduction Service No. ED417669).

Block, P. (1993). Stewardship: Choosing service over self-interest. San Francisco: Berrett-Koehler.

Blume, S.D., and Schwartz, S.W. (1994). Leadership. In W.C. Hartel, S.W. Schwartz, S.D. Blume, and J.N. Gardner (Eds.) Ready for the real world (pp. 239-253). Belmont, CA: Wadsworth Publishing Company.

Bowman, M.A. (1997). Popular approaches to leadership. In P.G. Northouse (Ed.) Leadership: Theory and practice (pp. 239-259). Thousand Oaks, CA: Sage Publishers.

Bridgman, D.S. (1930). Success in college and business. Personnel Journal, 9, 2.

Brubacher, J.S., and Rudy, W. (1974). Higher education in transition. New York: Harper and Row.

Bruins, J. Calvin. (1985). High school student activities and grades as predictors of adult accomplishments. (Doctoral dissertation, Arizona State University, 1985). Dissertation Abstracts International, 46, 0010.

Burns, G.P. (1978). The principles of leadership. San Antonio, TX: Our Lady of the Lake University. (ERIC Document Reproduction Service No. ED154700).

Burton, Arthur S. (1974). A comparative study in post-college leadership activities between college graduates selected as leaders and non-leaders. (Doctoral dissertation, Southern Illinois University, 1974). Dissertation Abstracts International, 35, 0714. 
Byer, J.L. (1998). Fraternity members' perceptions of how involvement in a fraternity and involvement on student government has influenced their college experiences. Washington, DC: Educational Resources Information Center. (ERIC Document Reproduction Service No. ED421956).

Calhoon, R.P., and Reddy, A.C. (1965, October-November). The frantic search for predictors of success: Fifty years of confusion and contradiction. Journal of College Placement, 54-66.

Calhoun, J. (1993). Utilizing youth as resources. Youth Policy, 15, 32-34.

Callahan, M.M. and Mabey, C. (1985). Undergraduate leadership development. AAHE Bulletin, 37(7), 3-6.

Campbell, A. (1981). The sense of well-being in America. New York: McGraw-Hill.

Campbell, D., and Stanley, J. (1963). Experimental and quasi-experimental designs for research. Chicago: Rand McNally.

Caruso, R. (1981). Rationale. In D.C. Roberts (Ed.), Student leadership programs in higher education. Carbondale, Il: Southern Illinois University Press/American College Personnel Association.

Chambers, Tony. (1992). The development of criteria to evaluate college student leadership programs: A Delphi approach. Journal of College Student Development, 33(4), 339-347.

Chapin, F.S. (1929). Extra-curricular activities at the University of Minnesota. Minneapolis, MN: University of Minnesota Press.

Chickering, A.W. (1981). Potential contributions of college unions to student development. In W.M. Klepper (Ed.), The impact of college unions and their programs on today's student. Stanford, CA: Association of College Unions International.

Chickering, A.W. (1969). Education and Identity. San Francisco: Jossey-Bass Publishers.

Chickering, A.W., and Reisser, L. (1993). Education and Identity. San Francisco: JosseyBass Publishers.

Christenson, G.A. (1969). The future of the university: A report to the people. Norman, OK: University of Oklahoma Press. 
Clark, K.E. (1985). Teaching undergraduates to be leaders. AAHE Bulletin 37(7), 11-14.

Covey, S.R. (1989). The seven habits of highly effective people. New York: Simon and Schuster.

Crist, B.E. (1999). A study of the relationship of job satisfaction of chief academic officers at institutions of higher education and the perceived leadership style of the institution's president. (Doctoral dissertation, West Virginia University, 1999). Dissertation Abstracts International, 61, 826.

Dillman, D.A. (1978). Mail and telephone surveys: The total design method. New York: John Wiley and Sons.

Doherty, M.S. (1995). Self-perceptions of gender role and leadership characteristics among female senior student organizational leaders and non-leaders. (Doctoral dissertation, Ohio University, 1995). Dissertation Abstracts International, 56, 3468 .

Downey, Ronald G., Bosco, Pat J., and Silver, Edward M. (1984). Long term outcomes of participation in student government. Journal of College Student Personnel, 25(3), 245-250.

Duncan, R., Mohrman, S.A., Mohrman, A., Cooke, R.A., and Zaltman, G. (1977). An assessment of a structured task approach to organizational development in a school system. Washington, DC: National Institute of Education, United States Department of Health, Education, and Welfare. (ERIC Document Reproduction Service No. ED168221).

Education Commission of the States. (1986). Transforming the role in undergraduate education: Time for a different view. Denver: Author.

Ellis, S.J. (2000). Why volunteer? Retrieved April 18, 2001, from http://www.volunteermatch.org/about/advice/why.jsp.

Erikson, E.H. (1963). Childhood and Society. New York: Norton.

Falvey, F.E. (1952). Student participation in college administration. New York: Bureau of Publication, Teachers College, Columbia University.

Florestano, Thomas E. (1970). The relationship of college leadership and post-college leadership as measured by the Leadership Opinion Questionnaire and a leadership inventory. (Doctoral dissertation, University of Maryland, 1970). Dissertation Abstracts International, 32, 0173. 
Frederick, R.W. (1959). The third curriculum: Student activities in American education. New York: Appleton-Century-Crafts, Inc.

Furlong, N.E., Lovelace, E.A., and Lovelace, K.L. (2000). Research methods and statistics: An integrated approach. Fort Worth, TX: Harcourt College Publishers.

Gambrill, B.L. (1939). College achievement and vocational efficiency. New York: Columbia University Press.

Gay, L.R. (1996). Educational research: Competencies for analysis and application. Upper Saddle River, NJ: Prentice-Hall, Inc.

Gibb, C.A. (1954). Leadership. In G. Lindsey (Ed.) Handbook of social psychology II. Reading, MA: Addison-Wesley Publishers.

Gordon, M., and Arvey, R. (1975). The relationship between education and satisfaction with job content. Academy of Management Journal, 18, 888-892.

Graham, S. and Cockriel, I. (1995, September). Indexes to assess social and personal development and the impact of involvement. Paper presented at the annual meeting of the Association for the Study of Higher Education. Orlando, Florida.

Graham, S. and Gisi, S.L. (2000). Adult undergraduate students: What role does college involvement play? NASPA Journal, 38(1), 99-121.

Gulick, L.H. and Urwick, L. (1937). Papers on the services of administration. New York: Institute of Public Administration, Columbus University.

Hardman, T.M. (1996). A study of job satisfaction of female public school administrators in West Virginia. (Doctoral dissertation, West Virginia University, 1996). Dissertation Abstracts International, 57, 2766.

Havemann, E. and West, P. (1952). They went to college. New York: Harcourt, Brace, and Company.

Herzberg, F. (1966). Work and the nature of man. Cleveland, OH: World.

Holloway, E.A. (1998). Candidates' and non-candidates' perceptions of student leadership factors at the University of Southern Mississippi. (Doctoral dissertation, The University of Southern Mississippi,1998). Dissertation Abstracts International, 59, 2384.

Human Resources Study Group of AT\&T. (1984). College experiences and managerial performance. New York: Author. 
Hunt, S. (1963). Income determinants for college graduates and the return to educational investment. Yale Economic Essays, 3, 303-357.

Jepson, V.L. (1951, March). College activities and vocational success. Occupations, 29, 345-347.

Johnson, C.W. (2000). Book review: Exploring leadership for college students who want to make a difference. NASPA Journal, 38(1), 143-147.

Kasworm, C. (1990). Adult undergraduates in higher education: A review of past research perspectives. Review of Educational Research, 60, 345-372.

Kerlinger, F.N. and Lee, H.B. (2000). Foundations of behavioral research. Orlando, FL: Harcourt College Publishers.

Kocher, E. and Pascarella, E. (1988). The effects of institutional transfer on status attainment. Paper presented at the meeting of the American Educational Research Association, New Orleans.

Kohlberg, L. (1969). Stage and sequence: The cognitive development approach to socialization. In D. Goslin (Ed.), Handbook of socialization theory and research (pp347-480). New York: Rand McNally.

Komives, S.R., Lucas, N., and McMahon, T.R. (1998). Exploring leadership: For college students who want to make a difference. San Francisco: Jossey-Bass Publishers.

Kraft, J.A. (1951). A ten-year follow-up study of graduates of a California junior College. (Doctoral dissertation, Stanford University, 1951). Dissertation Abstracts International, ADD, 0193.

Kreck, D., Crutchfield, R.S., and Ballackey, E.L. (1962). Individuals in society. New York: McGraw-Hill.

Krumboltz, J.D. (1957, January). The relationship of extracurricular participation to leadership criteria. Personnel and Guidance Journal. p. 310.

Kuh, G.D. (1993a). In their own words: What students learn outside the classroom. American Educational Research Journal, 30(2), 277-304.

Kuh, G.D. (1993b). Ethos: Its influence on student learning. Liberal Education, 79(4), 22-31. 
Kuh, G.D. (1995). The other curriculum: Out-of-class experiences associated with student learning and personal development. The Journal of Higher Education, 66 (2), 123-155.

Kuh, G.D. and Lund, J.P. (1994, Summer). What students gain from participating in student government. New Directions for Student Services, 66, 5-17.

LeBard, C. (1999). The relationship between American community colleges' curricular and extra-curricular programs and students ' perceptions of their leadership abilities. Washington, DC: Educational Resources Information Center. (ERIC Document Reproduction Service No. ED429625).

Lewin, K., Lippitt, R., and White, R.K. (1939). Patterns of aggressive behavior in experimentally created social climates. Journal of Social Psychology, 10, 271299.

Loeb, R., and Magee, P. (1992). Changes in attitudes and self-perceptions during the first two years of college. Journal of College Student Development, 33(4), 22-31.

Lucas, M.L. (1996). The origins of student life: A history of the colonial college extracurriculum at Rutgers and Princeton, 1800-1870. (Doctoral dissertation, Rutgers University, 1996). Dissertation Abstracts International, 57, 1979.

Mathis, S.G. (1999). The relationship of leadership frame use of departmental chairs to faculty job satisfaction as perceived by selected departmental faculty members. (Doctoral dissertation, West Virginia University, 1999). Dissertation Abstracts International, 60, 1936.

Maslow, A.H. (1968). Toward a psychology of being. New York. Harper and Row.

McIntire, D.D. (1989). Student leadership development: A student affairs mandate. NASPA Journal, 27(1), 75-79.

McKee, J.G. (1991). Leadership styles of community college presidents and faculty job satisfaction. Community/Junior College, 15, 33-46.

McMillon, K.L.R. (1997). Comparison of college student leadership programs from the 1970s to the 1990s. (Doctoral dissertation, University of North Texas, 1997). Dissertation Abstracts International, 58, 2561.

Miller, T.K., and Jones, J.D. (1980). Out of class activities. In A.W. Chickering (Ed.), The modern American college (pp. 675-691). San Francisco: Jossey-Bass. 
Minihan, A. (1957). The college union and preparation for citizenship. Ithaca, New York: Association of College Unions-International.

Moffatt, M. (1989). Coming of age in New Jersey: College and American culture. New Brunswick, NJ: Rutgers University Press.

Mohrman, A., Cooke, R, and Mohrman, S. (1978). Participating in decision making: A multidimensional perspective. Educational Administration Quarterly, 14(1), 13 29.

Mohrman, A., Cooke, R., Mohrman, S., Duncan, R., and Zaltman, G. (1977). An assessment of a structural task approach to the organizational development of a school system. Washington, DC: National Institute of Education.

Morrell, S.A. and Morrell, R.C. (1986). Learning through student activities. In P.S. Breivik (Ed.) New directions in higher education: Managing programs for learning outside the classroom. (pp. 77-87). San Francisco: Jossey-Bass.

Mundy, L.A., and Davis, J.C. (1974). Varieties of accomplishment after college: Perspectives on the meaning of academic talents. Iowa City, IA: American College Testing Service.

National Association of Student Personnel Administrators (1987). A perspective on student affairs: A statement issued on the 50 ${ }^{\text {th }}$ anniversary of The Student Personnel Point of View. Washington, DC: Author.

Newton, F.B. (1975). Development of student leadership on campus. Journal of College Student Personnel, 16(5), 422-427.

Newton, F.B., and Ender, K.L. (1978). Student development practices: Strategies for making a difference. Springfield, IL: Charles C. Thomas.

Niles, S.G., Sowa, C.J., and Laden, J. (1994). Life role participation and commitment as predictors of college student development. Journal of College Student Development, 33(4), 348-355.

Nolin, M.J., Chapman, C., and Chandler, K. (1997). Adult civic involvement in the United States: National household education survey. Washington, DC: National Center for Education Statistics. (NCES Report No. 97-906).

Pascarella, E.T., Ethington, C., and Smart, J. (1988). The influence of college on humanitarian/civic involvement values. Journal of Higher Education, 59(4), 412437. 
Pascarella, E.T. and Terenzini, P.T. (1991). How college affects students: Findings and insights from twenty years of research. San Francisco: Jossey-Bass.

Paul, W.L. (1992). Student leadership training: A key to improving the quality of college life. Kansas City, Missouri: Rockhurst College. (ERIC Document Reproduction Service No. ED204665).

Perkins, D.F. and Miller, J. (2000). Why community service and service learning? Providing rationale and research. Retrieved April 20, 2001, from http://www.quest.edu/content/Resources/ServiceLearningArticles/slarticle2.htm.

Pew Partnership for Civic Change. (1997). Civic Partners.. Charlottesville, VA: The University of Virginia. (ERIC Document Reproduction Service No. ED419062).

Power-Ross, S.K. (1980). Co-curricular activities validated through research. Student Activities Programming, 13, 46-48.

Randolph, A. (1974). Sampling: Looking at sample size and biases. Rehabilitation tomorrow, 4(8), 1-2.

Roskens, Ronald W. (1958). The relationship between leadership participation in college and after college. (Doctoral dissertation, State University of Iowa, 1958). Dissertation Abstracts International, 19, 0473.

Rudolph, F. (1962). The American college and university. New York: Vintage Books.

Sanford, N.E. (1966). Self and society. New York: Atherton Press.

Sawyer, D. (1999). Developing student leaders for Appalachia. Appalachian heritage, 28 (2), 28-34.

Schuh, John H., and Laverty, Mary. (1983). The perceived long-term influence of holding a significant student leadership position. Journal of College Student Personnel, 24 (1), 28-32.

Schultz, R.E., and Garrett, L.W. (1965). Junior college honor students who were initiated into Phi Theta Kappa for selected years during the period 1947-1965. Unpublished manuscript, Tallahassee, FL: Florida State University,

Sermershem, Katherine L. (1996). Undergraduate Greek leadership experiences: A proven method for gaining career related and life-long skills. Campus Activities Programming 29(3), 56-60. 
Shandley, Thomas C. (1988). Student leadership in the university: An analysis of the perceptions of student leaders and their peers. (Doctoral dissertation, The University of Minnesota, 1988). Dissertation Abstracts International, 49, 2555.

Sirk, J.P. (1999). Administrators' influence on job satisfaction for West Virginia special education teachers. (Doctoral dissertation, West Virginia University, 1990). Dissertation Abstracts International, 60, 1860.

Smitter, A. (1998, November). Leadership programs across the campus: Who's teaching what from where? The student affairs-administered program. Paper presented at the annual meeting of the National Communication Association, New York, NY.

Sommers, Walter B. (1991). Relationship between college student organization leadership experience and post-college leadership activity. (Doctoral dissertation, Oregon State University, 1991). Dissertation Abstracts International, 53, 0422.

Spears, L.C. (2001). Servant leadership: Quest for caring leadership. Retrieved March 3, 2001, from http://greenleaf.org/leadership/read-about-it/

Servant-Leadership-Articles-Book-Reviews.html

Stanford, S.W. (1992). Extracurricular involvement and development among undergraduate student leaders. College Student Affairs Journal, 12 (1), 17-24.

Stogdill, R.W. (1948, January). Personal factors associated with leadership: A survey of literature. Journal of Psychology, 25, 33-71.

Stogdill, R.W. (1974). Handbook of leadership: A survey of theory and research. New York: Free Press.

Street, J.L. (1997). Leadership development: A comparison of strategies for college student organizations. (Doctoral dissertation, The University of Georgia, 1997). Dissertation Abstracts International, 58, 2110.

Striffolino, P. and Saunders, S.A. (1989). Emerging leaders: Students in need of development. NASPA Journal, 27 (1), 51-58.

Swenson, M. (1983). Follow-up on student activities leaders. Proceedings of the $63^{\text {rd }}$ annual conference of the Association of College Unions-International, pp. 85-87.

Terenzini, P.T., Pascarella, E.T., and Blimling, G.S. (1996). Students' out-of-class experiences and their influence on learning and cognitive development: A literature review. Journal of College Student Development, 37(2), 149-162. 
Trow, M.A. (1997). American higher education: Past, present and future. In L.F. Goodchild and H.S. Wechsler (Eds.) The history of higher education (pp. 571 586). Needham, MA: Simon and Schuster.

Twale, D. (1988). Student development, part 1: Student activities: A critical link to the educational mission. American Sociological Review, 44, 831-842.

Walsh, G. (1970). What's the secret of leadership: Three historical approaches examine the mystery. College and university business, 49(1), 37-39.

Walters, R. and Bray, D. (1963). Today's search for tomorrow's leaders. Journal of College Placement, 24, 22-23.

Watts, W.D. (1988, October). Patterns of social fragmentation and cohesion: The social context of education for citizenship. Paper presented at the National Conference on Education, Washington, DC.

Whitt, E.J. (1994). I can be anything!: Student leadership in three women's colleges. Journal of College Student Development, 35 (3), 198-207.

Williams, R.L. (1991). The origins of federal support for higher education. In L.F. Goodchild and H.S. Wechsler (Eds.) The history of higher education (pp. 267272). Needham, MA: Simon and Schuster.

Wilson, E.K. (1966). The entering student: Attributes and agents of change. In T. Newcomb and E. Wilson (Eds.) College peer groups. Chicago: Aldine.

Yoakum, C.S. (1919). Plan for a personnel bureau in educational institutions. In G.L. Saddlemire and A.L. Rentz (Eds.), Student affairs - a professions' heritage: Significant articles, authors, and documents (pp. 4-8). Carbondale, IL: American College Personnel Association.

Zeleny, L. (1939). Characteristics of group leaders. Sociology and Social Research, 24, 140-149. 
APPENDICES 
APPENDIX A

The West Virginia College and Community Involvement Survey 


\section{The West Virginia College and Community Involvement Survey}

1. Please answer/indicate the following demographic information:

Age

Sex

Ethnicity:

White

Black

$\bigcirc$ Hispanic $\bigcirc$ Asian/Pacific Islander American Indian/Alaskan Native

2. Please indicate the college from which you graduated:

Other

Bluefield State College
Glenville State College
West Virginia State College

Concord College

$\bigcirc$ Shepherd College

Fairmont State College

West Liberty State College

3. Please indicate your undergraduate degree earned and your major field of study (i.e., B.A. in Humanities, B.S. in Biology, etc.).
4. Please indicate your current salary level:
$\bigcirc$ Under $\$ 10,000$
$\bigcirc \$ 10,001-\$ 20,000$
$\bigcirc \$ 20,001-\$ 30,000$
$\bigcirc \$ 30,001-\$ 40,000$
$\$ 40,001-\$ 50,000$
$\$ 50,001-\$ 60,000$
$\bigcirc \$ 60,001-\$ 70,000$
Over $\$ 70,000$

\section{Activities while you were in college...}

The following information pertains to your involvement and activities while you were enrolled in college. List organizations in which you were involved beside each category below. Then, indicate any elected or appointed offices held in that organization. Please use the back of the page if you need more space.

$\underline{\text { Name of Organization }}$

1. Honor Societies/Groups

(e.g., Cardinal Key, Gamma Beta Phi,

Pi Gamma Mu, etc.)

2. Service Organizations (e.g., Alpha Phi Omega, Rotoract, Student Ambassador, etc.)

\section{Student Government/}

Activities (e.g., Student Government

Senate, Program Board, etc.)

\section{Special Interest Groups}

(e.g., Groups related to major, Christian Fellowship, Phi Beta Lambda, Art Club, Kappa Delta Pi, Model UN, etc.)

\section{Sororities/Fraternities}

(e.g., Sigma Sigma Sigma, TKE,

Pi Kappa Phi, etc.)

\section{Elected or Appointed Offices}
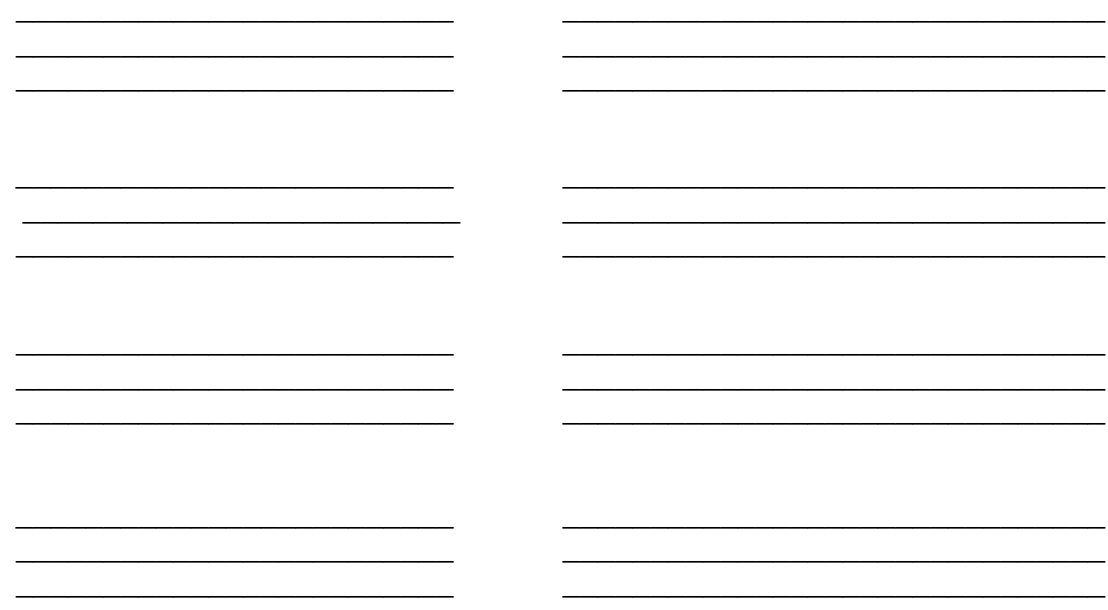

PLEASE CONTINUE ON PAGE TWO 


\section{Activities after you graduated from college...}

The following information pertains to your involvement and activities since you completed your four-year degree. List organizations in which you have been or are involved beside each category below. Then, indicate any elected or appointed offices held in that organization. Please use the back of the page if you need more space.

1. Social/Interest Groups

(e.g., card clubs, garden clubs

dance groups, sororities, etc.)

2. Civic Organizations

(e.g., Kiwanis, Lions, Rotary,

Woman's Club, Quota, etc.)

\section{Service Groups}

(e.g., school boosters, vol. fire/rescue,

4-H, Union Mission, humane society, etc.)

\section{Religious Organizations}

(e.g.,Deacon, choir, Sunday School Teacher, church council, etc.)

5. Fraternal Organizations

(e.g., Moose Lodge, Masonic Lodge, etc.)

\section{Recreational Groups}

(e.g., community sports teams, leagues, etc.)

7. Military Organizations

(e.g., VFW, Vietnam Veterans' Org., etc.)

8. Professional Organizations

(e.g., organizations related to your employment or profession.)

\section{$\underline{\text { Name of Organization }}$}

\section{Elected or Appointed Offices}
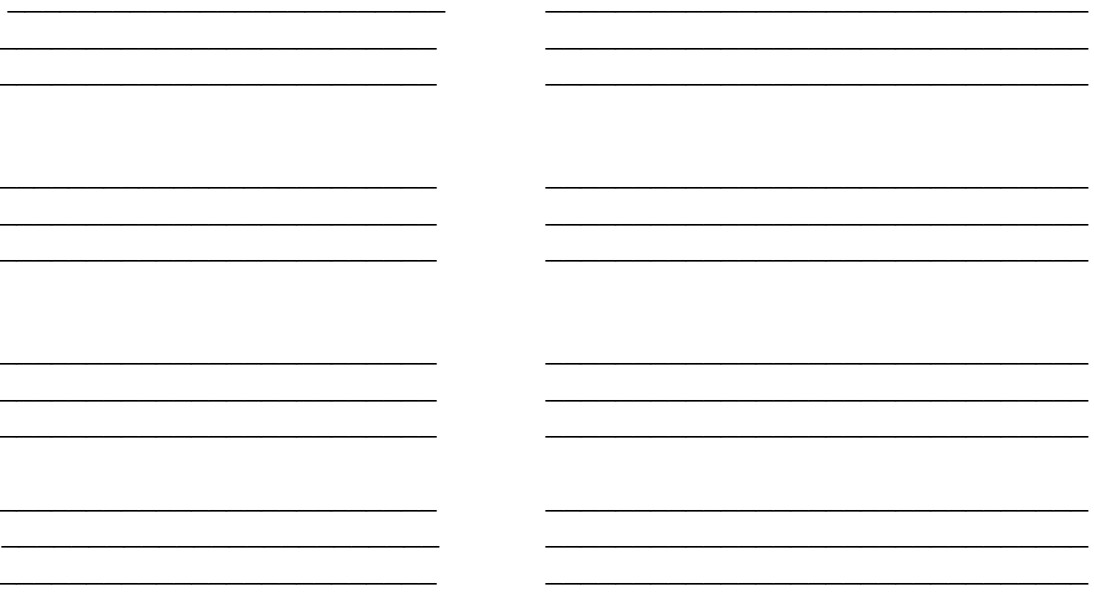

$\underline{ }$
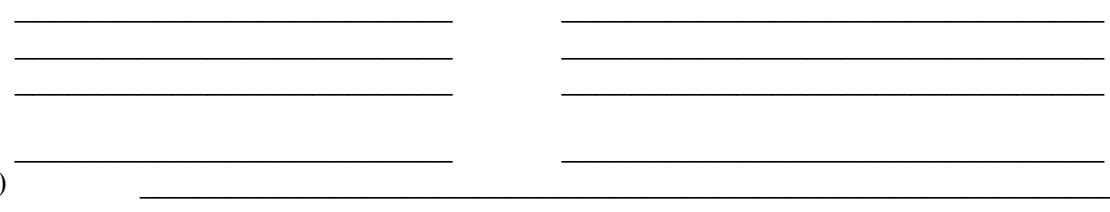

)

$+$


APPENDIX B

The Mohrman-Cooke-Mohrman Job Satisfaction Survey 


\section{The Mohrman-Cooke-Mohrman Job Satisfaction Scales*}

Please indicate your level of satisfaction with various facets of your job by circling a number on the six-point scale after each of the statements.

\begin{tabular}{|lll|}
\hline Intrinsic Satisfaction & Low & High
\end{tabular}

1. The feeling of self-esteem or self-respect you get from being in your job.

$\begin{array}{llllll}1 & 2 & 3 & 4 & 5 & 6\end{array}$

2. The opportunity for personal growth and development in your job.

3. The feeling of worthwhile accomplishment in your job.

$\begin{array}{llllll}1 & 2 & 3 & 4 & 5 & 6\end{array}$

4. Your present job when you consider the expectations you

had when you took the job.

$\begin{array}{llllll}1 & 2 & 3 & 4 & 5 & 6\end{array}$

$\begin{array}{llllll}1 & 2 & 3 & 4 & 5 & 6\end{array}$

\section{Extrinsic Satisfaction}

Low

High

5. The amount of respect and fair treatment you receive from your superiors.

6. The feeling of being informed in your job.

7. The amount of supervision you receive.

$\begin{array}{llllll}1 & 2 & 3 & 4 & 5 & 6 \\ 1 & 2 & 3 & 4 & 5 & 6 \\ 1 & 2 & 3 & 4 & 5 & 6 \\ 1 & 2 & 3 & 4 & 5 & 6\end{array}$

8. The opportunity for participation in the determination of methods, procedures and goals.

* Developed by Allan M. Mohrman, Jr., Robert A. Cooke, and Susan Albers Mohrman

\section{Please return the survey in the self-addressed stamped envelope provided. Your assistance in completing this survey is greatly appreciated.}


APPENDIX C

Cover Letter to Sample Population 


\section{West VirginiaUniversity}

\section{College of Human Resources and Education}

August 2001

Dear 1990 College Graduate,

You have been selected to participate in a research study of college graduates from fouryear State colleges in West Virginia from 1990. Through this study, we hope to learn more about student participation in extra-curricular activities. YOUR response will help colleges in West Virginia plan better programs and services for college students in the State.

Please know that your participation in this study is voluntary. You may choose not to respond to any part of the study. Your responses will remain anonymous and you will not be identified individually in this or any subsequent reports. This research project was reviewed and approved by the Human Subjects Review Board of West Virginia University.

I understand that you are extremely busy and that your time is valuable. The enclosed survey instrument will only take approximately five minutes to complete. The West Virginia College and Community Involvement Survey will ask a few questions about you, activities in which you participated while in college, and activities that you have participated in since you graduated. The Mohrman-Cooke-Mohrman Job Satisfaction Survey will ask about your level of satisfaction with your current employment.

I am conducting this survey as my dissertation for the Doctoral program in Higher Education Administration at West Virginia University. Your help in completing this survey would be greatly appreciated. Since the completion of my degree depends on you, I would be EXTREMELY grateful for your help!

Please return the completed survey in the enclosed prepaid reply envelope by September 1, 2001. Your help is greatly appreciated.

Sincerely,

J.D. Carpenter

Doctoral Candidate

West Virginia University

Enclosure 
APPENDIX D

Follow-up Letter to Sample Population 


\section{WestVirginiaUniversity}

\section{College of Human Resources and Education}

September 2001

Dear 1990 College Graduate,

Recently, you received from me a letter and survey instruments requesting your help with a research project concerning your involvement in college and community activities. If you have completed and returned the survey, please consider this letter my expression of gratitude for your participation and help. If you have not yet completed the survey, please consider this a final plea for your assistance. I have enclosed an additional survey instrument and return envelope for you, if needed.

Please know that your participation in this study is voluntary. You may choose not to respond to any part of the study. Your responses will remain anonymous and you will not be identified individually in this or any subsequent reports. This research project was reviewed and approved by the Human Subjects Review Board of West Virginia University.

Please return the completed survey in the enclosed prepaid reply envelope by September 15, 2001. Your help is greatly appreciated.

$$
\text { Sincerely, }
$$

J.D. Carpenter

Doctoral Candidate

West Virginia University

Enclosure

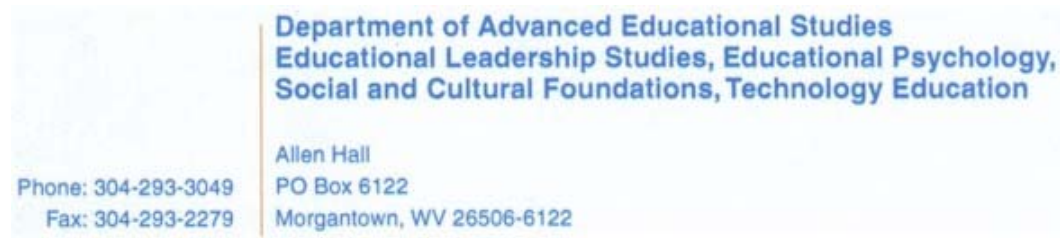

Equal Opportunity/Affirmative Action Institution 


\section{CURRICULUM VITAE}




\title{
James D. (J.D.) Carpenter \\ P.O. Box 1502, Bluefield, WV 24701 \\ 304.589.4166 (H) - 304.253-7351 (Ext. 1584) (W)
}

blc01256@mail.wvnet.edu

B.S.R. (cum laude), Wildlands Recreation Management, WEST VIRGINIA UNIVERSITY, Morgantown, WV. 1989.

M.S., Recreation with emphasis in Public Administration, WEST VIRGINIA UNIVERSITY, Morgantown, WV. 1991.

Ed.S., Educational Leadership, MARSHALL UNIVERSITY GRADUATE COLLEGE, South Charleston, WV. 2000.

Ed.D.., Educational Leadership, WEST VIRGINIA UNIVERSITY, Morgantown, WV. 2002.

\section{Highlights of Qualifications}

Student-centered professional with thirteen years of experience in higher education

Skilled in organization, personnel, and budget management

Experience working with diverse populations and international students

Active in state, regional and national professional organizations

Generalist, with experience in many areas related to student development and administration

\section{Relevant Experience}

\begin{abstract}
Associate Vice President for Operations, Mountain State University, Beckley, WV, 2001-Present.
General areas of responsibility include Physical Plant, Dean of Students, Residence Life, Bookstore, Dining Services, Security (including reporting responsibilities for the Clery Act and the Students' Right to Know Act), Telecommunications, and Risk Management. Supervision of five directors, indirect supervision of 24 full time and 30 part time employees and an operational budget in excess of $\$ 2,000,000.00$. Redesigned communication systems for the reservation and use of campus space. Planned and implemented a complete renovation project for the University Bookstore, including the installation of a point-of-sale purchasing and inventory control system. Supervised various capital renovations, including Dining Services and a new School of Business. Planned for improvements in space utilization and supervision in the University residence hall, including construction of office space and the redesign and implementation of paperwork processes to ensure better communication with, and services for, students. Directed divisional efforts in strategic planning and assessment. Re-established presence and role of student affairs and student development on campus, including role of chief judicial officer. Served as on-call administrator to manage crisis situations within areas of responsibility. Represented interests of divisional departments to senior management officers.
\end{abstract}

Director of Campus Life, Division of Student Affairs, Bluefield State College, Bluefield, WV, $1995-2001$.

Directed the operations of the Campus Life Office, including the Student Union and Student Activities. Advised the Student Government Association and the Greek Council. Oversaw Student Publications (yearbook and newspaper), intramurals, homecoming, cheerleading and off-campus housing. Served as liaison officer for all student organizations, and managed the College calendar and facilities, including swimming pool, fitness center and tennis courts, and developed leadership training activities and retreats. Wrote grant proposals and secured funding for student programs. Developed computer presentations, videos and displays to assist in promoting the institution. Supervised four professional and approximately 30 paraprofessional employees and a departmental budget in excess of $\$ 250,000.00$. Served as Project Administrator for National Youth Sports Program Grant, recognized nationally as best first-year project in 1999. Duties also included assisting in the development of New Student Orientation, serving as the College representative to the Advisory Board of Classified Employees to the State College System Central Office, Classified Staff Senate, College Council, and various hiring committees. Chair of the Student Union Board and Student Activities Committee. Served on North Central Association Accreditation Self-Study Assessment Committee, 2000. 
Director of Residence Life, Office of Student Affairs, Salem-Teikyo University, Salem, WV, $1994-95$.

Responsible for the management of seven residence areas housing 700+ students, hiring and training professional (4) and paraprofessional (25) staff, collaborated relationships with other campus offices (admissions, business office, security, etc.), re-designed programming efforts in an attempt to better educate and provide activities for students and take advantage of the multi-cultural environment. Responsible for the residence hall judicial system, developed public relations material for the department, supervised communication, designed and managed room selection process, developed employee manuals, served on various University committees, provided counseling services for students, and developed departmental budget. Committee work included Computer Systems, Fall Orientation, Student Retention, Physical Plant Assessment, Student Code, and Japanese Student Orientation.

\section{Resident Director, Office of Student Residential Life, Concord College, Athens, WV, 1991-94.}

Administered the daily operation of a 150-room College residence facility, including coordination of building services, resident assistant programming and policy enforcement, supervised and scheduled seven paraprofessional staff and 12-15 desk attendants, coordinated room selection/assignments for the entire campus, including five facilities and 900+ students, revised and prepared instruction manuals and handbooks for residence life staff and students, counseled students and intervened in crisis situations. Involved in the coordination of staff hiring and training and advised residence hall governing bodies.

\section{Adjunct Professor, Department of Travel Industry Management, Concord College, Athens, WV, 1992-94}

Developed, presented and administered the following courses: Travel Industry Management 456 - Senior Seminar/Program Planning and Administration, Travel Industry Management 260 - Concepts in Leisure.

\section{Related Experience}

Graduate Resident Assistant, Dept. of Housing and Residence Life, West Virginia University, Morgantown, WV, $1989-91$.

Night Staff Supervisor, Dept. Of Housing and Residence Life, West Virginia University, Morgantown, WV, $1989-91$.

Naturalist/Activity Director, Bluestone State Park, Hinton, WV, and Chief Logan State Park, Logan, WV, Summers 1988/89.

\section{Professional Activities}

Gamma Beta Phi National Honor and Service Society.

National President, 1998-99. National President-Elect, 1997-98. National Vice President, 1996-97.

NEC Advisor Member, 1994-96. Served as chapter advisor and State Advisor, 1991-1999.

National Association of Student Personnel Administrators (NASPA)

Region II Advisory Board, Newsletter Editor - 1997-2000.

Region II Membership Services Coordinator - 2000-Present.

West Virginia Association of Student Personnel Administrators (WVASPA)

Past President, 1999-2000. President, 1998-1999. President Elect - 1997-98.

Executive Committee, Newsletter Editor - 1995-1997, NASPA Liaison - 2000-Present. Innovative Program Award - 1997.

Outstanding Service Award - 2001.

National Association of Campus Activities (NACA), 1995-1999.

Advisory Council of Classified Employees to the State College System of West Virginia, 1996-1998.

National Clearinghouse for Commuter Programs, 1998-2001.

Association for the Promotion of Campus Activities (APCA), 1998-Present.

West Virginia Membership Coordinator, 1998-Present.

Recipient of the 2001 Ernest C. Jones Award for Excellence in Programming 


\section{Conference and Workshop Presentations}

\section{Strategic Planning for Student Affairs and Student Organizations}

National Association of Student Personnel Administrators Region II Conference, Pittsburgh, PA, November 1999.

West Virginia Association of Student Personnel Administrators Annual Conference, Davis, WV, October 1999. Association for the Promotion of Campus Activities National Conference, Knoxville, TN, March 1999. Association for the Promotion of Campus Activities, Student Government Retreat, Savannah, GA, August 1999.

\section{Working with Groups in Difficult Situations}

West Virginia Association of Student Personnel Administrators Annual Conference, Davis, WV, October 1998. Association for the Promotion of Campus Activities National Conference, Atlanta, GA, February 1998. Fairmont State College/WVASPA Leadership Retreat, Fairmont, WV, February 1998.

WV State College and University System Staff Retreat, Charleston, WV, September 1997. Gamma Beta Phi West Virginia State Convention, Green Valley, WV, September 1997.

Concord College Residence Life Training, Athens, WV, August 1997.

Bluefield State College Leadership Retreat, Bluefield, WV, June 1997.

\section{It's a Culture Thing: Understanding Perceptions of Different People}

State College and University System/State EEO Training and Development Conference, Pipestem, WV, October 2001.

Concord College Residence Life Training, Athens, WV, August 2001.

West Virginia Association of Collegiate Registrars and Admissions Officers, Flatwoods, WV, July 2001.

Wytheville Community College Phi Theta Kappa Leadership Conference, Wytheville, VA, March 2000.

University of Charleston Student Leadership Retreat, Charleston, WV, January 2000.

State College and University System/State EEO Training and Development Conference, Wheeling, WV, October 1999.

West Virginia Association of Student Personnel Administrators Annual Conference, Davis, WV, October 1997.

Concord College Residence Life Training, Athens, WV, August 1997.

Bluefield State College Leadership Retreat, Bluefield, WV, June 1997.

Gamma Beta Phi National Convention, Nashville, TN, March 1997.

\section{Breaking the Ice and Building Your Teams}

Gamma Beta Phi National Convention, Nashville, TN, March 1998.

\section{Using Technology in Campus Activities}

West Virginia Association of Student Personnel Administrators Annual Conference, Snowshoe, WV, October 1996.

\section{Publications}

Carpenter, J.D. (2002). Co-Curricular Involvement of West Virginia Four-Year State College Students and the statistical relationship with subsequent sommunity and professional involvement, salary, and job satisfaction. Unpublished doctoral dissertation. West Virginia University, Morgantown, WV.

Carpenter, J.D. (2000, March). Developing a strategic plan for your residence life program. Residence Life Executive. March, 2000. Paperclip Communications: Garfield, NJ.

Carpenter, J.D. (2000, March). Developing a strategic plan for your orientation program. Orientation Executive. March, 2000. Paperclip Communications: Garfield, NJ.

Carpenter, J.D. (1999). Advanced programming and personal development. In E. Lambert (Ed.), Association for the Promotion of Campus Activities Advisor Handbook. (Available from the Association for the Promotion of Campus Activities, 1131 South Fork Drive, Sevierville, TN 37862) 
Carpenter, J.D. (1991). Images presented by the National Park Service: A content analysis of National Park brochures. Unpublished master's thesis. West Virginia University, Morgantown, WV.

Burrus-Bammel, L.L., Bammel, G., Kopitsky, K., and Carpenter, J.D. (1988). Assessing your agency's image: The perspective given to the public through public relations material. In L. Beck (Ed.), Research in Interpretation: Proceedings of the 1988 National Association of Interpretation Research Symposium (pp. 1-12). San Diego: San Diego State University.

\section{Other Activities}

First Christian Church, Princeton, WV

Choir Director and Song Leader - 2000-2001.

Parkview Baptist Church, Bluefield, WV

Youth Committee, Properties Committee, Sunday Night Celebration Committee, Substitute Worship and Song Leader -

1996-2000, 2001-Present

Basset Hound Rescue of Old Dominion

West Virginia State Coordinator, 1999-Present. 2001 Volunteer of the Year.

Instructor, Community First Aid and CPR, American Red Cross, 1994-1999.

Advisor, Baptist Campus Ministries, Salem-Teikyo University, 1994-95.

Volunteer Firefighter/First Responder/Admin. Sec., Athens Volunteer Fire Dept., Athens, WV, 1992-94. 